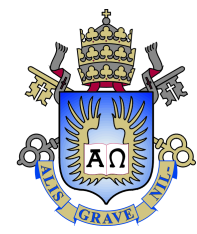

Mateus Proença Morais

\title{
Public Banks and Access to Conditional Cash Transfer Programs
}

Dissertação de Mestrado

Thesis presented to the Programa de Pós-graduação em Economia, do Departamento de Economia da PUC-Rio in partial fulfillment of the requirements for the degree of Mestre em Economia.

Advisor: Prof. Juliano Assunção 


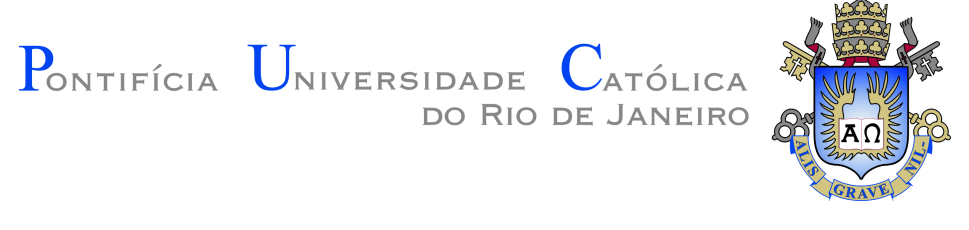

Mateus Proença Morais

Public Banks and Access to Conditional Cash
Transfer Programs

Thesis presented to the Programa de Pós-graduação em Economia da PUC-Rio in partial fulfillment of the requirements for the degree of Mestre em Economia. Approved by the Examination Committee:

Prof. Juliano Assunção

Advisor

Departamento de Economia - PUC-Rio

Prof. Leonardo Rezende

Departamento de Economia - PUC-Rio

Prof. Gabriel Ulyssea

Department of Economics - University College London

Rio de Janeiro, April the 16th, 2021 
All rights reserved.

\section{Mateus Proença Morais}

B.A. in Economics, Escola de Economia de São Paulo Fundação Getulio Vargas, 2018

Bibliographic data

Morais, Mateus Proença

Public Banks and Access to Conditional Cash Transfer Programs / Mateus Proença Morais; advisor: Juliano Assunção. -2021.

56 f: il. color. ; $30 \mathrm{~cm}$

Dissertação (mestrado) - Pontifícia Universidade Católica do Rio de Janeiro, Departamento de Economia, 2021.

Inclui bibliografia

1. Economia - Teses. 2. Politicas Públicas. 3. Transferência de Renda. 4. Infraestrutura. 5. Expansão Bancária. I. Assunção, Juliano. II. Pontifícia Universidade Católica do Rio de Janeiro. Departamento de Economia. III. Título. 


\section{Acknowledgments}

To my advisor Juliano Assunção, who guided and disciplined my research endeavors. His support made this project possible, and his ideas and suggestions arguably improved my research quality. I would also like to thank Profs. Leonardo Rezende and Gabriel Ulyssea for participating in the Examination Committee.

To my parents, Janaina and Silvio, and my sister, Alice, for their love and patience. Anything I accomplish is yours as well. I can put in words how thankful I am for having you all by my side.

To Arthur Bragança. The time I spent at Climate Policy Initiative (CPI) under your supervision taught me a lot and made me a better researcher.

To Coordenação de Aperfeiçoamento de Pessoal de Nível Superior - Brasil (CAPES) who financed my Master's studies and allowed me to dedicate myself entirely to Research. The financial support from PUC-Rio is also gratefully acknowledged. 


\section{Abstract}

Morais, Mateus Proença; Assunção, Juliano (Advisor). Public Banks and Access to Conditional Cash Transfer Programs. Rio de Janeiro, 2021. 56p. Dissertação de Mestrado - Departamento de Economia, Pontifícia Universidade Católica do Rio de Janeiro.

In this work, I study public banks' role in implementing Conditional Cash Transfer Programs (CCTs). Using an entry model with heterogeneous firms inspired by Bresnahan \& Reiss (1991), I can determine how the Bolsa Família program in Brazil impacts Caixa Econômica Federal and other bank's decisions differently. I also evaluate whether beneficiaries are able to effectively access the Bolsa Família program when there is no financial institution in their municipality. Exploiting variation in bank coverage following a Central Bank resolution, I also find that fewer benefits are withdrawn in municipalities without a bank, causing involuntary cancellations of the program. The results suggest that bank coverage is a relevant aspect of the implementation of cash transfer policies and that public banks can be effective in simultaneously improving access to public policies and financial services.

\section{Keywords}

Policy; Cash Transfer; Infrastructure; Banking Expansion. 


\section{Resumo}

Morais, Mateus Proença; Assunção, Juliano. Bancos Públicos

e Acesso à Programas de Transferência Condicionada de Renda. Rio de Janeiro, 2021. 56p. Dissertação de Mestrado Departamento de Economia, Pontifícia Universidade Católica do Rio de Janeiro.

Neste trabalho, estudo o papel dos bancos públicos na implementação de Programas de Transferência Condicionada de Renda (CCTs). Usando um modelo de entrada com firmas heterogêneas inspirado em Bresnahan \& Reiss (1991), consigo determinar como o programa Bolsa Família no Brasil impacta as decisões da Caixa Econômica Federal e de outros bancos de forma diferente. Também avalio se os beneficiários do programa têm acesso efetivo ao Bolsa Família quando não há instituição financeira em seu município. Explorando variação na cobertura bancária após uma resolução do Banco Central, também encontro que menos benefícios são retirados em municípios sem banco, causando cancelamentos involuntários do programa. Os resultados sugerem que cobertura bancária é um aspecto relevante na implementação de políticas de transferência de renda e que bancos públicos podem ser eficazes na melhoria simultânea do acesso às políticas públicas e a serviços financeiros.

\section{Palavras-chave}

Politicas Públicas; Transferência de Renda; Infraestrutura; Expansão Bancári. 


\section{Table of contents}

1 Introduction $\quad 10$

2 Literature Review 13

3 Institutional Background $\quad 15$

$\begin{array}{lll}3.1 & \text { Banking System } & 15\end{array}$

3.2 Bolsa Família program 20

4 Data 24

$5 \quad$ Structural Analysis $\quad 26$

$\begin{array}{lll}5.1 & \text { Model } & 26\end{array}$

$\begin{array}{lll}5.2 & \text { Equilibrium } & 28\end{array}$

$\begin{array}{lll}5.3 & \text { Estimates } & 32\end{array}$

5.4 Counterfactual Analysis 34

6 Reduced Form Analysis $\quad 38$

6.1 Empirical Strategy 38

6.2 Main Results 39

6.3 Event Study 41

6.4 Robustness 43

$\begin{array}{lll}7 & \text { Conclusion } & 47\end{array}$

$\begin{array}{ll}\text { Bibliography } & 49\end{array}$

A Appendix $\quad 53$

A.1 Estimation Procedure 53

A.2 Credit Trends $\quad 54$

A.3 Complete Estimates of the Model 56 


\section{List of figures}

$\begin{array}{lll}\text { Figure 3.1 Banking Expansion by type of bank } & 16\end{array}$

Figure 3.2 Banking Coverage and points of sale by Bank 18

Figure 3.3 Credit per Municipality Trends 19

Figure 3.4 Credit per Agency Trends 20

Figure 3.5 Beneficiaries of the Bolsa Família Program by Region 22

$\begin{array}{llr}\text { Figure 5.1 Simplified Model Equilibria } & 29\end{array}$

Figure 5.2 Simplified Model Equilibria, Imposing Selection Mechanism 30

Figure 5.3 Estimated Coefficients from 2004 to 2009.

Figure 5.4 Counterfactual Banking Coverage 35

Figure 5.5 Counterfactual Banking Coverage in 2004

Figure 6.1 Event Study Specification 42

Figure A.1 Credit per Municipality Trends 54

Figure A.2 Credit per Agency Trends 55 


\section{List of tables}

$\begin{array}{lll}\text { Table } 4.1 & \text { Descriptive Statistics } & 25\end{array}$

Table 5.1 Joint Distribution of Banks in January 2004

Table 5.2 Main Estimates of the Model 32

Table 5.3 Characteristics of Counterfactual Municipalities 37

Table 6.1 Regressions linking Caixa Econômica Federal's Coverage to Bolsa Família's Cancelled Benefits. 40

Table 6.2 Regressions linking Caixa's Agencies per 10 Thousand to Bolsa Família's Cancelled Benefits. 44

Table 6.3 Regressions linking Distance to the Nearest Caixa Econômica Federal to Bolsa Família's Cancelled Benefits. 45

Table A.1 Complete Estimates of the Model 56 


\section{Introduction}

Conditional Cash Transfer programs (CCTs) are essential mechanisms to help provide a minimal standard of living for all citizens and alleviate adverse situations such as unemployment, sickness, and disabilities (Fiszbein \& Schady (2009)). Additionally, the program's condicionalities incentivize vulnerable families, especially children, to access health and education services that may break the cycle of intergenerational persistence of poverty. Programs have been shown to impact inequality (Soares et al. (2010)), child's health (Gertler (2004)), educational attainment (García \& Saavedra (2017)), and even women's health and emancipation levels (Barber \& Gertler (2009)).

However, one aspect that is frequently set aside is its complicated logistics. Governments usually rely on banks to distribute these policies. Still, most developing countries have yet to universalize access to financial services, which may hinder people from withdrawing their benefits, especially in vulnerable and remote areas. This paper explores the relationship between banking coverage and access to CCTs.

Brazil's context offers fertile ground to study this question. The Bolsa Familia program (PBF), the most extensive CCT in the world (Shei et al. (2014)), has a cancellation protocol for families that fail to withdraw their benefits for six months which allows indirect verifiability of adequate access to the program. Also, because Brazil opted to distribute the policy through its banking system, it is possible to study the relationship between banking coverage and PBF's distribution. Caixa Econômica Federal (Caixa), the bank with highest coverage in the country, solely distributes PBF, which allows me to analyze the effect that policy distribution may have on banks' operations.

The article uses a dual approach, combining Structural and Reduced Form Analysis to answer two related but different questions and extend the knowledge on the relationship between banking coverage and CCT delivery. First, I develop an entry model with heterogeneous banks to analyze how the Bolsa Familia program differently affected Caixa and other banks' spatial distribution. Considering that Caixa may value expanding to remote areas to reach potential beneficiaries, the program may alter equilibrium coverage. The model's main contribution is to establish how the incentives generated by 
the distribution of policies interact with competition effects to shape banks' decisions.

The structural model estimates that, in 2004, Caixa is indifferent between entering a municipality with $\mathrm{R} \$ 398$ (US\$69.70) less GDP per capita and entering a municipality with one extra percent of Bolsa Familia beneficiaries. After estimation, I analyze a counterfactual scenario in which PBF did not exist or, equivalently, Caixa did not value its distribution. This exercise shows that Caixa's efforts to distribute PBF significantly accelerated bank coverage in remote areas, with more than 1000 additional municipalities having coverage at one point due to the program. Also, municipalities in the counterfactual are more impoverished, less populated, and have a higher percentage of $\mathrm{PBF}$ beneficiaries.

As a second research question, I evaluate the effect of banking infrastructure on adequate access to the PBF. Exploiting variation in Caixa 's coverage and Bolsa Familia 's cancellation rules, I can estimate the impact of banking coverage on families' effective access to the program. Specifically, I investigate if cancellations rise when Caixa leaves a municipality and, conversely, if cancellations decline when Caixa enters it. My main specification is a simple Differences-in-Differences approach with variation in treatment timing, in which I find that Caixa 's presence in a municipality reduces the number of cancellations of Bolsa Familia by 9,9\%. I also estimate placebo specifications and verify that Banco do Brasil and private banks' coverage do not affect program cancellations.

The results are akin to an event-study model. I find that cancellations decrease when Caixa covers a municipality, with reductions of up to $50 \%$ in the number of cancellations in its peak, at the second month of banking coverage. Results also indicate no anticipation effects, which strengthens the hypothesis that cancellations rise is due to access constraints.

Additionally, I perform two robustness exercises. First, I use a similar approach to the main specification but replacing Caixa 's coverage with the number of Caixa 's per 10 thousand inhabitants. Effects remain significant although smaller, which suggests that opening additional Caixa agencies have little impact on PBF and, for most municipalities, one Caixa should be enough to guarantee proper distribution of benefits.

Second, I investigate it the distance to the nearest Caixa affects cancellations. Contrary to previous estimates, effects are not robust. Nevertheless, this finding does not contradict the main results. It indicates that conditional on Caixa 's absence, it does not matter whether the family needs to withdraw its benefits in a close or a far away municipality. Traveling to another municipality 
entails high costs for these low-income families, which is sufficient to hinder access to benefits.

This paper main's contribution is highlighting infrastructure's role in providing access to CCT programs in developing countries. While these concerns might go unnoticed in implementing similar programs in developed countries, it is vital to keep in mind that rural and remote areas in the third world may not have facilities such as banks. Although specific Brazilian institutions may partially cause this paper's results, this paper shows that accessibility should arguably be a central concern in elaborating any CCT on poor or developing countries.

The remainder of the paper is organized as follows: Chapter 2 reviews the related literature, Chapter 3 describes the Brazilian banking environment and the Bolsa Família program. Chapter 4 describes the Data. Chapter 5 develops the model used to study how policies may differently impact banks' spatial distribution, estimates it, and provides a counterfactual analysis. Reduced form evidence on banking infrastructure's role in access to CCTs is discussed in Chapter 6. Section 7 concludes. 


\section{2}

\section{Literature Review}

There is a vast literature on Conditional Cash Transfer programs. Fiszbein \& Schady (2009) discusses the main aspects of this type of program and its prominent examples worldwide. Several papers evaluate the impact of specific CCTs, such as Soares et al. (2010) for the Bolsa Família program and Gertler (2004) for the PROGRESA program in Mexico, finding robust results in poverty alleviation and child health. García \& Saavedra (2017) provides a meta-analysis of CCTs focusing on educational impacts and their costeffectiveness, finding significant heterogeneity between programs. There is also a literature that focuses on specific aspects of these programs or correlates outcomes, such as Barber \& Gertler (2009) on CCTs' role on women's access to high-quality health care and women's empowering and Zucco Jr (2013) that shows the political payoffs of implementing the Bolsa Familia program in Brazil. This paper's contribution to this discussion is analyzing an aspect of these programs that is often overlooked: the importance of infrastructure for adequate access in remote areas.

This paper also speaks to the literature that studies banking expansion and competition. An industrial organization literature focuses on creating models that reflect the main economic trade-offs faced by banks. Joaquim et al. (2019), for instance, develop a spatial competition model between financial service providers and provides a framework in industrial organization to study competition and information frictions in the banking sector. Some papers also study the economic environment after an exogenous change in competition parameters in a more applied setting. Gao et al. (2019) documents the economic consequences of a bank entry deregulation in China and show that it leads to higher screening standards, lower interest rates, and lower delinquency rates for corporate loans from entrant banks.

Specifically, this paper is related to previous literature that studies banking expansion and competition in Brazil. Kumar et al. (2006) documents the regulation of banking correspondents in Brazil and Assunção (2013) uses an entry model to show that this reform drastically reduced costs for operation in new markets, allowing banking coverage to increase in the 2000s decade (Banco Central do Brasil (2010)). Müller (2017) evaluates the impact of banking 
correspondents in urban areas, particularly in Brazilian slums, and relates financial inclusion to reduced violence. Coelho et al. (2012) studies another factor contributing to banking expansion in Brazil: the payroll experiment of 2003. This reform allowed repayment through automatic payroll deduction, which significantly decreased credit risk and allowed banks to expand credit. Finally, Coelho et al. (2013) estimates the competition effects between public and private banks, concluding that public banks do not significantly affect private banks' operations.

There is also a literature that focuses on the social aspect of banking expansion and contrasts public and private banks' roles. Burgess \& Pande (2005) evaluates the welfare effects of expanding bank coverage to remote areas. It concludes that rural banks' expansion contributed to reducing poverty in India. Assuncao et al. (2012) develops a dynamic model that describes spatial competition in Thailand between commercial and public banks. The authors show that public banks affect coverage and spatial distribution because they care about access to financial services. Wijesiri et al. (2019) considers the existence of a trade-off between social and financial performance of public banks while Sapienza (2004) and Coleman \& Feler (2015) study the effects of government ownership on bank lending. The former focuses on the political incentives public banks may have to favor some lenders, while the latter shows the anti-cyclical potential of public credit during an economic crisis. 


\section{3 \\ Institutional Background}

\section{1}

\section{Banking System}

The Brazilian banking system is characterized by the coexistence between private and public banks and remained relatively stable until the end of the 1990s decade (Coleman \& Feler (2015)), even though Brazil experimented with profound economic and social changes since the 1960s, becoming increasingly industrialized and urbanized.

Caixa Econômica Federal, a public bank founded in 1861, became progressively responsible for distributing most of the Brazilian social policies such as income and food subsidy and school grants since the 1990s (Kumar et al. (2006)). It is the bank with the most prominent coverage in Brazil (as Banco Central do Brasil (2010) claims, and Figure 3.2 illustrates), mainly because it committed to distributing a wide range of policies. Today, it distributes most of the social programs that need a bank in Brazil, such as Fundo de Garantia por Tempo de Serviço (FGTS), Financiamento Estudantil (FIES), Bolsa Família and Minha Casa Minha Vida.

The other main public bank in Brazil is Banco do Brasil (BB), which was founded on October 12th, 1808, and was the first banking institution to operate in the country, being responsible for currency issue until the creation of the Central Bank in December 1964. Formerly a typical public bank, performing functions of both commercial and development banks, shifted its focus after 2001, and its operations became similar to private banks (Andrade \& Deos (2009)).

Unlike Caixa, lending constituted a large part of Banco do Brasil's proposed business. Its operation focused mostly on the informal market by offering micro-credit loans and low-cost accounts (Kumar et al. (2006)). It also has an important role as a source of rural credit. Banco do Brasil is also quite different from Caixa because it is a mixed ownership company, with the government owning just about $50 \%$ of the shares of the company. Its ownership structure is one reason for its bigger focus on credit and smaller adherence to public programs. 
The private banking sector in Brazil is somewhat concentrated. The major banks to operate in Brazil are Itaú, Bradesco and Santander. These banks provide, together with Caixa and BB, most of the country's financial services and constitute most of the branches and banking correspondents that I aggregate in the Private Banks category in my analysis.

Resolution 2640/99 was a resolution enacted by the Brazilian Central Bank to regulate and allow a steep increase in the number of Banking Correspondents. Banking Correspondents are institutions that provide financial services on behalf of a bank. Usually, banking correspondents are set at a Post Office or a lottery retailer that offers those services while simultaneously maintaining its original business.

As shown by Assunção (2013) and Loureiro et al. (2011), it is much cheaper to open a banking correspondent than a branch since there is no need to invest in new infrastructure or hire many employees. This Resolution enabled Caixa, along with other banks, to spread to regions that were not economically viable before.

Figure 3.1: Banking Expansion by type of bank
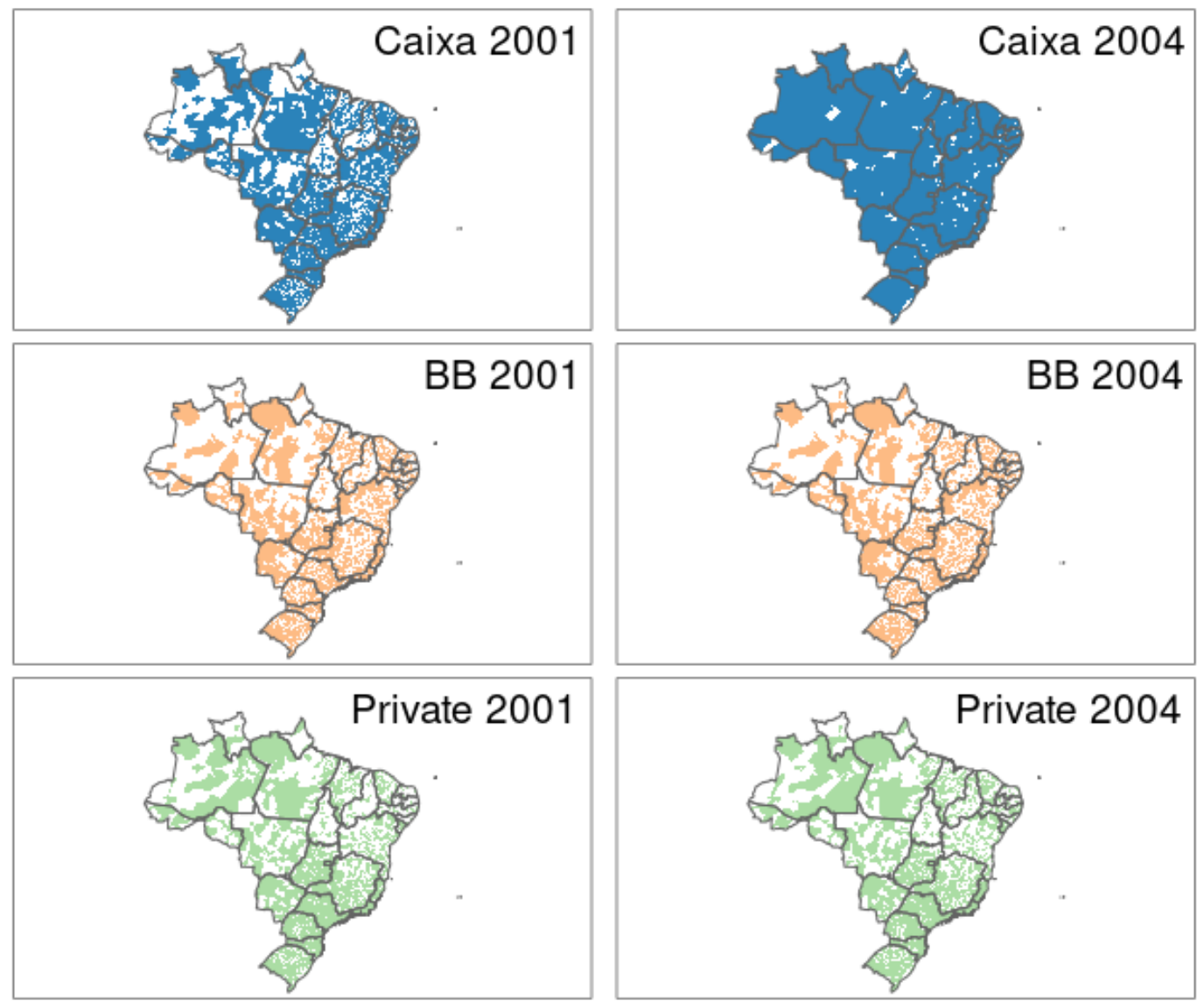

Notes: Both Agencies and Banking Correspondents were considered in the Graph. Caixa stands for Caixa Econômica Federal and BB stands for Banco do Brasil 
Another possible cause for banking expansion was the 2003 Brazilian Payroll experiment, which allowed workers to use their payroll and retirement benefits to get loans. The experiment vastly decreased credit cost and enabled banks to lend more and expand to previously unprofitable areas (Coelho et al. (2012)).

Along with Caixa and Banco do Brasil, the two banks that most expanded their banking correspondents operations after Resolution 2640/99 were Lemon Bank and Bradesco. Lemon Bank was a venture created in June 2002 that only operated through banking correspondents and focused on the unbanked public in dense urban areas. On the other hand, Bradesco is one of Brazil's major banks and used the banking correspondents legislation to expand its coverage through the creation of Banco Postal, a subsidiary that offered banking services in post offices. Bradesco paid $R \$ 200$ million (about $U S \$ 35$ million) for exclusive access to 5,300 of the 10,500 post offices in Brazil. The purchase was also significant for the increase in banking coverage since government regulation stipulated that Banco Postal should be present in at least 1,000 new municipalities covered by the Postal office.

Figure 3.1 compares banking coverage between 2001 and 2004 for Caixa, Banco do Brasil, and Private Banks. The graph shows Caixa expanded its operations to almost all municipalities by 2004, even remote areas in the Amazon. In contrast, BB and the Private banks did not significantly expand their coverage in the period even though banking correspondents had enabled expansion at a relatively low cost. The map is useful to highlight the geographical aspect of their differences. Caixa expanded to remote areas it was not present before, such as the Amazon, the interior of Piaui and Tocantins, areas with smaller potential for new accounts or credit.

Figure 3.2 shows a complete picture of banking expansion from 2001 to 2010. The first panel describes intensive margin expansion from Caixa, Banco do Brasil, and Private Banks. Banking coverage expanded greatly in this decade. The graph reports that BB and the Private Banks significantly expanded their operations after 2004, although they do not reach Caixa's almost universal coverage.

In the extensive margin, however, the situation is the opposite. The second panel of Figure 3.2 reports the number of banking points of sale in Brazil. Points of sale are defined as the sum of branches and banking correspondents. Private banks experienced a more than fourfold expansion in the decade, expanding their 40 thousand points of sale to more than 160 thousand by the end of 2010, while BB and Caixa only experienced a modest expansion after 2006 and 2008, respectively. 
Figure 3.2: Banking Coverage and points of sale by Bank
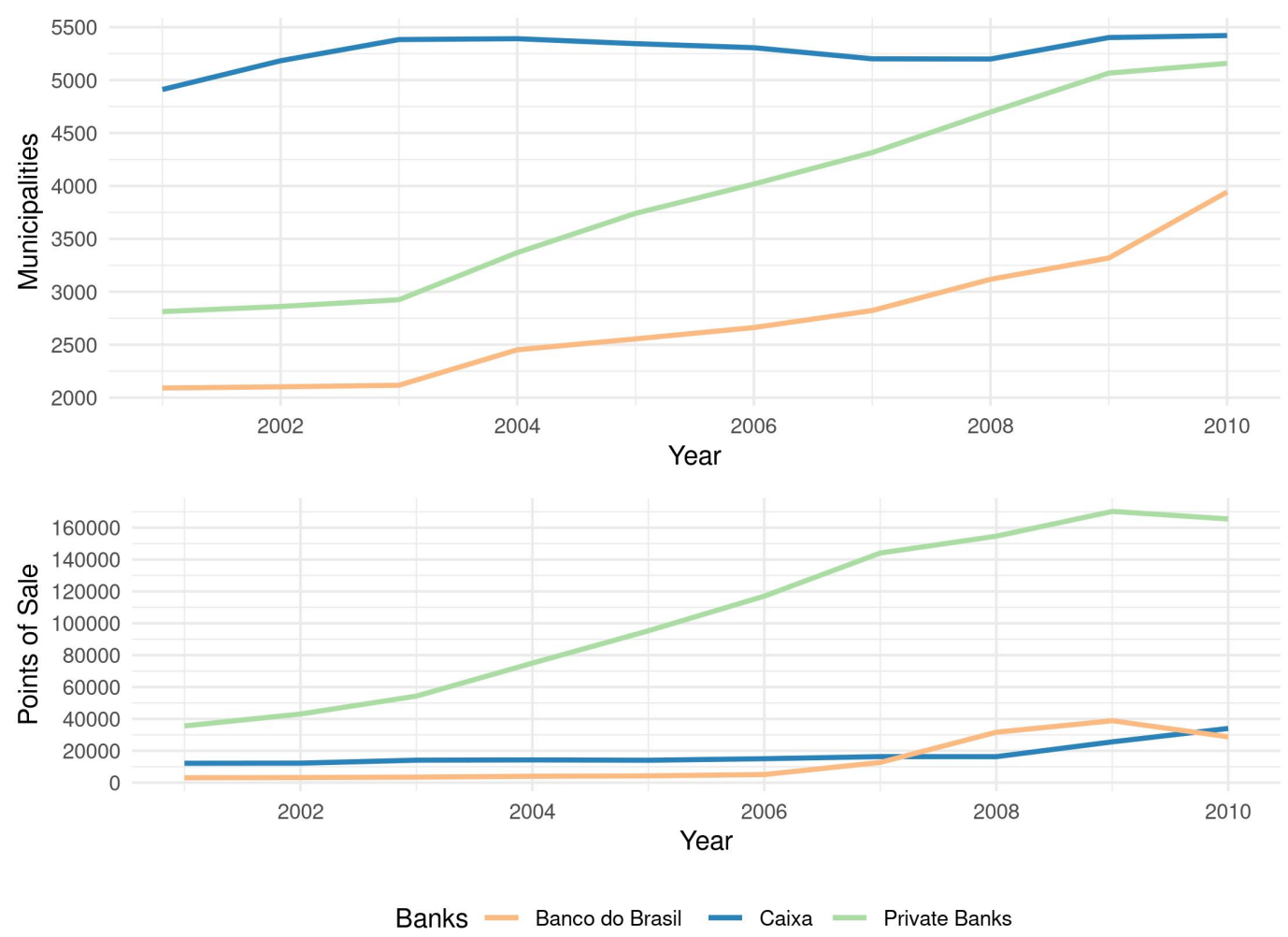

Notes: Both Agencies and Banking Correspondents were considered in the Graph.

The relationship between banking coverage and monthly average credit per municipality is reported in Figure 3.3. Each point represents one year between 2001 and 2010. Year indicators were omitted for graphic clarity, but a version that includes them is in Appendix A.2. Years can also be easily inferred since both points of sale and banking coverage were continuously growing over the period.

The figure exposes that credit per municipality expanded considerably for all banks in the period, especially private banks, along with coverage and points of sale spread. The credit per municipality increases can be explained by an increase in credit demand due to favorable macroeconomic conditions and social inclusion of the period. Note that movements in credit per municipality seem to be correlated with both points of sale and banking coverage, with a weaker relationship in Caixa's operation.

Figure 3.4 plots the number of points of sale and banking coverage in Brazil against average monthly credit per point of sale for Caixa, Banco do Brasil and private banks. Once again, each point represents a year between 2001 and 2010, and year indicators were omitted for graphic clarity. A version with years indicators is included in Appendix A.2 but years can be easily inferred since both points of sale and banking coverage were continuously 
Figure 3.3: Credit per Municipality Trends
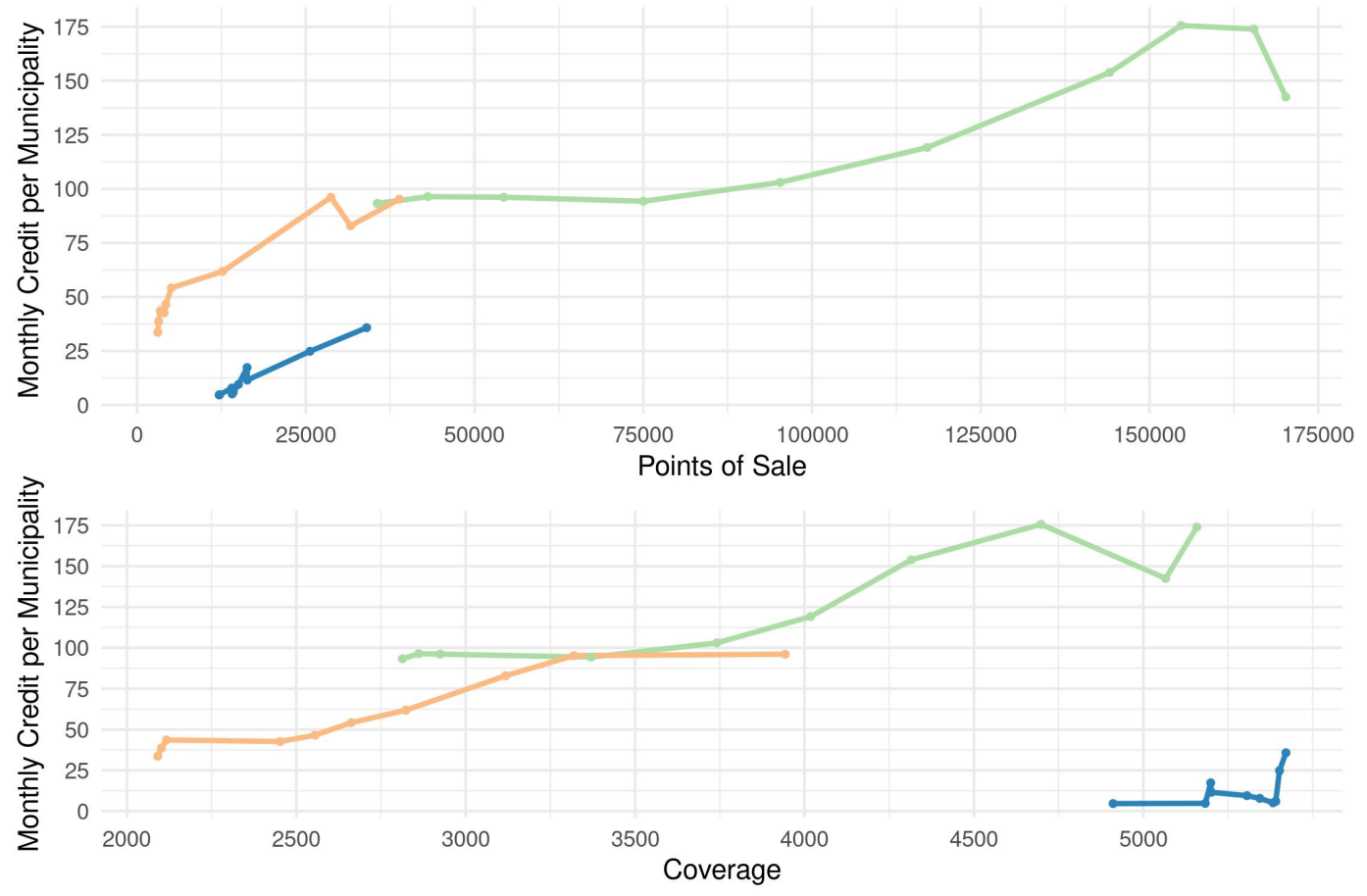

Banks - Banco do Brasil - Caixa - Private Banks

Notes: Both Agencies and Banking Correspondents were considered in the graph. Credit's unit is Million Reais (R\$). Each dot represents a year between 2001 and 2010. Indicators of each year were omitted for graphic clarity but can be inferred since both Total Agencies and Coverage increased in the period for all Banks. Version with year indicators in Appendix A.2.

growing over the period.

The credit per point of sale decreases for all banks in the period, except Caixa whose credit per point of sale increases. This fact suggests that both BB and private banks expanded their operations to unburden existing points of sale from the increasing demand for credit and financial services. Since some municipalities are still not profitable with current economic growth levels and GDP per capita, BB and private banks choose not to cover some remote areas.

The information on Figures 3.3 and 3.4 evaluated jointly indicate that the credit market size increased significantly between 2001 and 2010 and that $\mathrm{BB}$ and private banks opened new points of sale to adequate their operations to this new situation. In contrast, Caixa's expansion does not seem to be related to excess credit demand. Other factors should explain its expansion and higher coverage than its competitors. The model in 5 indicates that Caixa's behavior is less motivated by profitability than other banks and is associated with the distribution of Bolsa Familia's benefits. 
Figure 3.4: Credit per Agency Trends
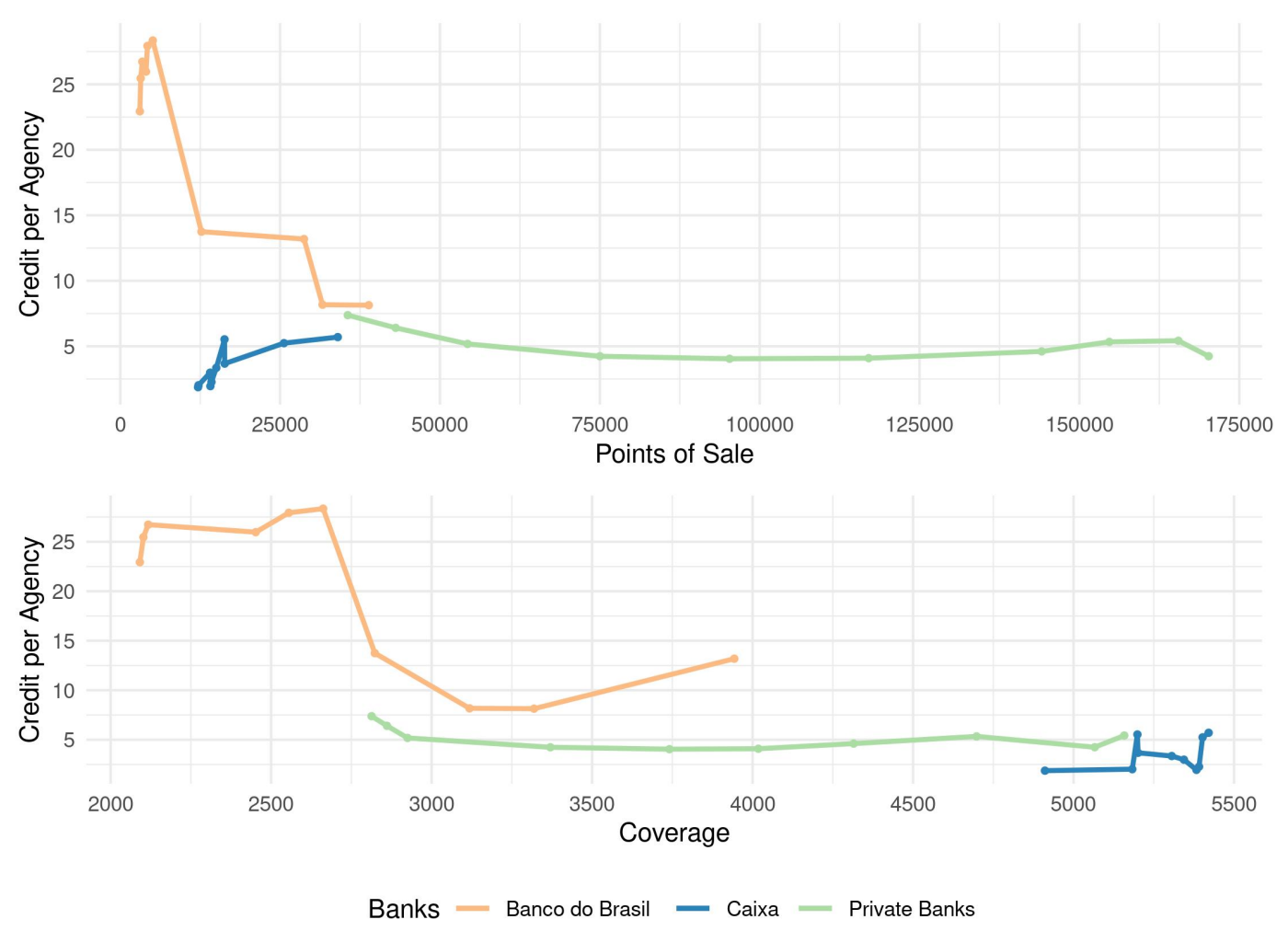

Notes: Both Agencies and Banking Correspondents were considered in the graph. Credit's unit is Million Reais (R\$). Each dot represents a year between 2001 and 2010. Indicators of each year were omitted for graphic clarity but can be inferred since both Total Agencies and Coverage increased in the period for all Banks. Version with year indicators in Appendix A.2.

\section{2}

\section{Bolsa Família program}

The Bolsa Familia program (PBF), created in October 2003 by the Brazilian Federal Government, is the most extensive Conditional Cash Transfer program (CCT) in the world (Shei et al. (2014)). It unified pre-existing Conditional and Unconditional Cash Transfer programs such as Bolsa Alimentação, Bolsa Escola, Cartão Alimentação, and Auxílio Gás. It is highly regarded as a very successful public policy in reducing inequality and extreme poverty (Soares et al. (2006)) while improving educational outcomes with low costs (see Soares et al. (2010) for a complete impact evaluation, Neri et al. (2013) for the macroeconomic effects of the program, and Ribeiro et al. (2017) for a survey on its central studies).

The program was designed to alleviate poverty while simultaneously ending its cycle of intergenerational persistence. It acts on three different dimensions: first, the direct cash transfers unburden families from current penury condition. Second, the condicionalities ensure that families registered 
at the program satisfy a set of requirements related to children's health and education outcomes, enabling children to have an upbringing that prepares them for future labor-markets opportunities and breaking the cycle of poverty. Finally, the complementary actions aim to create direct opportunities for families to improve their standards of living.

There is also a vital autonomy aspect to the program. The benefits are credited directly to the beneficiaries' accounts, and they are entirely free to choose how to spend their money. Also, despite the beneficiary unit being the whole household, benefits are given preferentially to women, strengthening women's autonomy and subverting potentially oppressing power dynamics in the household.

Eligibility for the program includes extremely poor and poor families, those whose income per capita less than $\mathrm{R} \$ 85(\mathrm{US} \$ 14.87)^{1}$ and $\mathrm{R} \$ 170(\mathrm{US} \$ 29.74)$ per month respectively, with children or pregnant women. The basic benefits' values are $\mathrm{R} \$ 85$ (US $\$ 14.87$ ) per month for extremely poor families plus additional variable benefits that depend on the number of children, teens, and pregnant women in the family. There is also an extra benefit for those families that continue extremely poor after benefits, whose value is at least the exact quantity they need to overcome extreme poverty.

For a complete description of the program and a deeper discussion of PBF's main aspects, see Lima et al. (2018) and Medeiros et al. (2007).

Figure 3.5 describes the evolution of Bolsa Familia program's beneficiaries from 2004 to 2019, by region. There was a significant expansion in the program in its first years due to its decentralized operation that delegates to municipal managers the task of reaching low-income families and registering them on the program. The funds that each municipality receives for the program are linked to its success in expanding coverage and its transparency in declaring its expenses, as reflected by the Índice de Gestão Descentralizada(IGD-M).

All regions follow similar trends in the period, experiencing a slight decline in the percentage of the population that receives benefits in the recent years, after a rapid expansion in its genesis. The Northeastern region has the highest percentage of beneficiaries, closely followed by the Northern region. It was somewhat expected since, compared to other regions, they have smaller GDP per capita and higher poverty rates.

Caixa Econômica Federal, as defined in Law No. 10,836 from January 9, 2004, is the only bank authorized to pay the Bolsa Familia's benefits. Among its obligations are the organization of the benefit payment logistics and reports for the program's inspection. Given the size and relevance of the Bolsa Familia

\footnotetext{
${ }^{1}$ All conversions from Reais to US Dollars were based on April's 1st 2021 quotation.
} 
Figure 3.5: Beneficiaries of the Bolsa Familia Program by Region

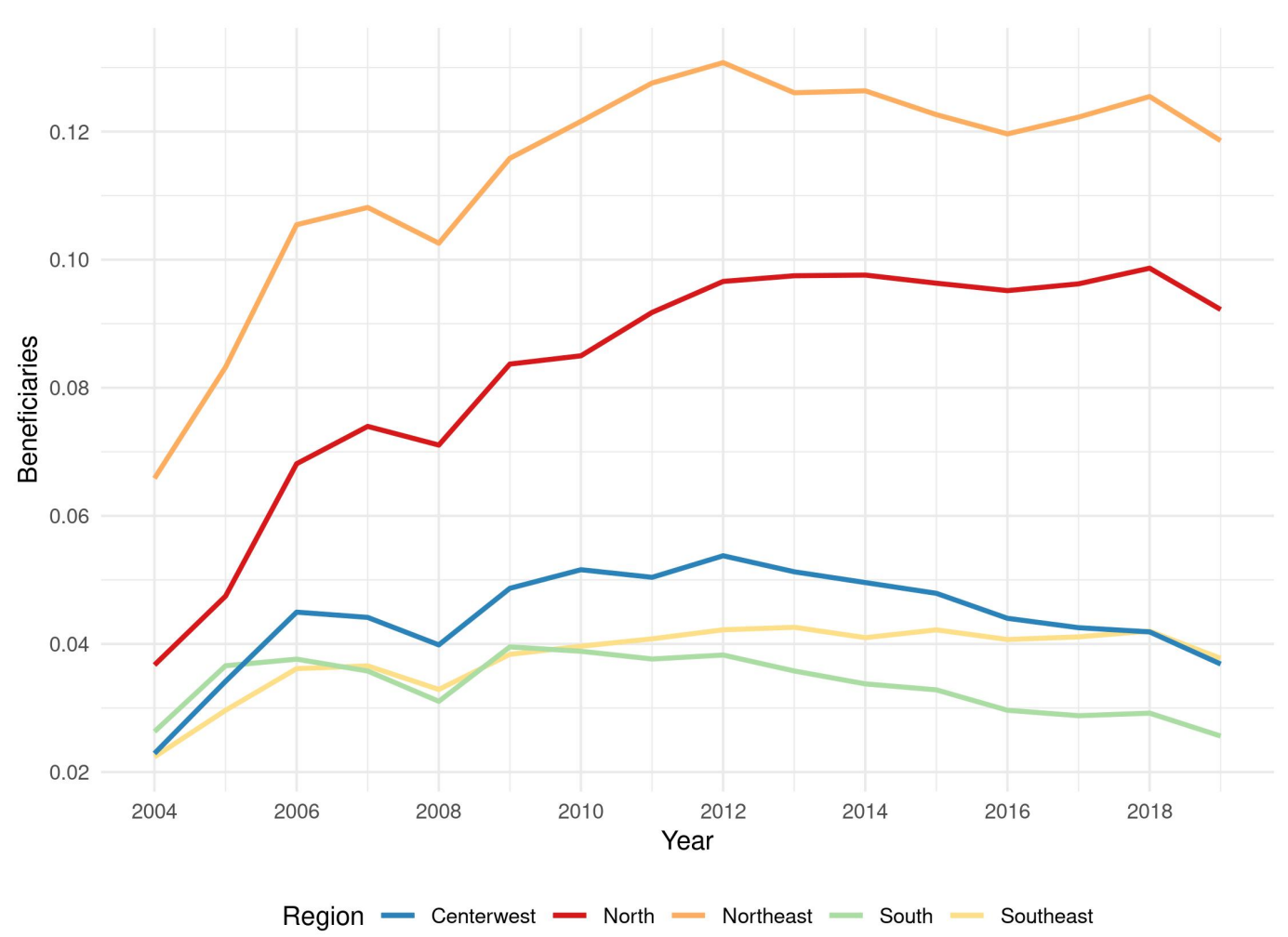

Notes: Beneficiaries show the percentage of the Population that receives Bolsa Familia's benefits.

program, Caixa committed to covering all municipalities in Brazil. If it had no branch or banking correspondent in the municipality for some reason, it would summon task forces to guarantee the distribution of benefits.

The logistics have not always worked perfectly tough, as some municipalities remained without access to any Caixa for a long time since the beginning of the program. Nevertheless, Caixa radically expanded its operations in the years that preceded the policy and continued to do so in the following years. It is also important to emphasize that the program's expansion is the municipal program managers' responsibility and does not depend on Caixa's decisions in any form. Caixa was only responsible for distributing the benefits to those beneficiaries who were already enrolled.

On average, 2,1\% of the Bolsa Familia benefits are canceled every month. Among other reasons, PBF has a rule that determines cancellation of benefits if recipients do not withdraw their benefits in six months. The federal government assumes that these families do not need cash transfers anymore.

However, when there is no Caixa coverage in the municipality, families would need to travel to other municipalities to access their benefits. Considering the typical beneficiary is an extremely poor family with small children, 
travels may be too costly. Families would need to lose a working day, arrange childcare and buy a bus ticket to access their benefits, which may cost more than their entitlements. Also, Table 4.1 reports that there are occurrences of families that needed to travel more than 200 Kilometers until the nearest Caixa.

Since the cost of traveling to other municipalities may be too high for impoverished families, many beneficiaries may be unable to withdraw their benefits, being involuntarily excluded from these programs. Chapter 6 investigates if families are able to effectively access the Bolsa Família program when there is no Caixa coverage in the municipality. 


\section{4 \\ Data}

I use four primary sources of data for the analysis presented in this paper. First, the number of Bank Branches for each bank in the municipality level is taken from the Brazilian Central Bank's database ESTBAN. I also have information on which services each Banking Correspondent provides, so I can filter which ones are relevant to the study. From this source, I also use the Credit variable. Although it is not used in my main analysis, I use to construct the variables Credit per Municipality and Credit per Agency, which appear on Figures 3.4 and 3.3. Data is available from 1990 to 2020.

Second, the information on banking correspondents, institutions that provide financial services in behalf of a bank, is available since 2014 in the Correspondentes no País database. I was also able to access data on banking correspondents from 1990 to 2020 through the Lei de Acesso a Informação (LAI), a Brazilian data transparency law.

I choose to aggregate information from branches and banking correspondents since, for my purposes, they are equivalent. I have the exact date each branch and banking correspondent opened and closed, which I choose to aggregate in monthly frequency to make it compatible with the other variables. I also choose to use this data only since 2004, which is when the Bolsa Familia program starts. Exceptions are Figures 3.1, 3.2, 3.4, and 3.3, which use data since 2001 to describe Coverage and Credit trends.

These two databases culminate on the variables of coverage, number of agencies (branches and banking correspondents) and distance to nearest agency, which are created for Caixa Econômica Federal, Banco do Brasil and Private Banks, which are all aggregated into the same category.

Third, the data on the Bolsa Familia program is available at a monthly frequency in the Ministério de Desenvolvimento Social's (MDS) website, and I use the number of beneficiaries and the value of benefits from the program from 2004 to 2019. The number of cancelled and blocked benefits, which I use as dependent variable in our main regressions, is also available at the website but only from 2014 to 2019. Ideally, I would use cancellation data since 2004, when the program started, but data for the first years of the program is not yet consolidated in the Ministry's archives. 
Finally, from the Instituto Brasileiro de Geografia e Estatística (IBGE), I use the Gross Domestic Product (GDP) from 2004 to 2018, the latest available data, and estimated population for municipalities from 2004 to 2019. This data is annual, so I will need to assume that they are constant throughout the year. Official municipality and state shapefiles are also available at their website, which I use to elaborate the maps and to construct the distance variables.

Table 4.1 reports the Descriptive Statistics for all the main variables used in the analysis.

Table 4.1: Descriptive Statistics

\begin{tabular}{lcccccc}
\hline \hline Statistic & Mean & St. Dev. & Min & Max & $\mathrm{N}$ & Range \\
\hline Caixa Coverage & 0.966 & 0.181 & 0 & 1 & $1,068,905$ & $2004-2019$ \\
BB Coverage & 0.728 & 0.445 & 0 & 1 & $1,068,905$ & $2004-2019$ \\
Private Coverage & 0.887 & 0.316 & 0 & 1 & $1,068,905$ & $2004-2019$ \\
\# of Caixas & 4.940 & 35.212 & 0 & 3,117 & $1,068,905$ & $2004-2019$ \\
\# of BBs & 4.406 & 18.918 & 0 & 1,801 & $1,068,905$ & $2004-2019$ \\
\# of Private Banks & 38.435 & 297.992 & 0 & 25,316 & $1,068,905$ & $2004-2019$ \\
Distance to Caixa & 0.807 & 5.717 & 0 & 232.831 & $1,068,900$ & $2004-2019$ \\
Distance to BB & 7.311 & 18.274 & 0 & 378.031 & $1,068,900$ & $2004-2019$ \\
Distance to Private & 3.285 & 12.774 & 0 & 291.796 & $1,068,900$ & $2004-2019$ \\
BF Beneficiaries & 2,152 & 7,403 & 0 & 511,168 & $1,068,722$ & $2004-2019$ \\
BF Benefits & 282 & 1,001 & 0 & 77,561 & $1,068,705$ & $2004-2019$ \\
Population & 35.2 & 207.9 & 0.8 & 12,252 & $1,068,852$ & $2004-2019$ \\
GDP per Capita & 14.528 & 17.709 & 0 & 815.7 & $1,001,952$ & $2004-2018$ \\
Cancellations & 42.380 & 289.941 & 0 & 43,748 & 388,791 & $2014-2019$ \\
Cancellations per 1000 & 20.745 & 28.440 & 0 & 450 & 388,786 & $2014-2019$ \\
\hline
\end{tabular}

Notes: All variables are at the Municipality Level and available at a Monthly Frequency, except Population and GDP per Capita, which are annual but extrapolated to Monthly Frequency. Caixa Coverage, BB Coverage and Private Coverage are Dummy variables indicating Bank's Coverage in the Municipality. \# of Caixas, \# of BBs and \# of Private Banks indicates the number of points of sale for each bank in the Municipality. Distance to Caixa, Distance to BB and and Distance to Private are the Distance in Kilometers to the Nearest Agency. BF Benefits and Population's unit is thousands and GDP per Capita's unit is Thousand Reais $(\mathrm{R} \$)$.

Caixa Coverage, BB Coverage, and Private Coverage are Dummy variables indicating Bank's Coverage in the Municipality. \# of Caixas, \# of BBs, and \# of Private Banks indicate the number of points of sale for each bank in the municipality. Distance to Caixa, Distance to BB, and Distance to Private are the distances in Kilometers to the Nearest Agency, calculated as the distance of the municipality's centroid to the nearest municipality with an agency's centroid. 


\section{5}

\section{Structural Analysis}

\section{1 \\ Model}

This chapter proposes a model that characterizes the determinants of bank entry decisions in Brazilian municipalities, extending the models from Bresnahan \& Reiss (1991) and Assunção (2013) to incorporate the distribution of public policies in banks' decisions. The model gives us measures of the monetary value Caixa attributes to attending extra beneficiaries of the program, which helps us evaluate their incentives and decide the best ways to implement policies that rely on financial institutions. I will also see how banks' priorities changed over time, allowing me to create a counterfactual banking coverage in Brazil in a scenario where Caixa does not care about distributing Bolsa Familia benefits. The counterfactual allows measuring the impact that the distribution of policies had on the Brazilian banking expansion.

Given the relevance of banks for financial services and the possibility of delivering cash transfer programs, it is essential to characterize how banks behave in practice, what determines their decisions of entrance and exit in a given market, and find optimal policies. As described before, every bank distributes financial services, but only Caixa distributes policy (Bolsa Familia). The model's main contribution is to establish how the incentives generated by the distribution of policies shape banks' distribution.

There are two main mechanisms governing banking coverage decisions: on the one hand, banks want to expand their operations to get access to a new market and increase their credit and deposit operations. On the other hand, the market structure may affect profitability. Also, in the case of Caixa Econômica Federal, there is potentially a third incentive, distributing Bolsa Família benefits to its beneficiaries. My model aims to quantify each factor's relevance in banks' decisions and deepen the understanding of the patterns of competition in the Brazilian banking sector.

The model fits in the category of multiple-agents qualitative response models, surveyed by Reiss (1996). This category of models is appropriate to characterize an economic environment when interacting agents use strategic 
behavior to determine the equilibrium outcomes. They allow the possibility of incorporating game-theory tools to an empirical problem and unveiling the underlying economic incentives that justify equilibrium behavior.

The framework is a static entry model with many agents (bank branches) distributed in two types of banks, Caixa and Other Banks. The category Other Banks includes both Banco do Brasil and all the Private Banks. The main difference between types is that Caixa distributes the CCT program and may value extended access to the program. Branches are defined as the game's agents for simplicity.

Each branch decides whether to enter each market (municipality). If a branch decides not to enter a market, its profit is zero and, adapting from Mazzeo (2002), type $i$ branch's profit, if they decide to enter market $m$, is given by:

$$
\Pi_{i m}=\operatorname{Pop}_{m}\left(\alpha Y_{m}+\lambda_{i} P B F_{m}\right)-\Gamma_{i i} *\left(\# i_{m}-1\right)-\Gamma_{i j} *\left(\# j_{m}\right)-F+\varepsilon_{i m}
$$

Where $Y_{m}$ is the municipality's GDP per capita in thousand Reais $(R \$)$, $P B F_{m}$ is the percentage of beneficiaries of Bolsa Família in municipality $m$, $F$ is the fixed cost of operating in a new market, $\# i$ is the number of same type branches in the market, $\# j_{m}$ is the number of different type branches in the market, and $\varepsilon_{i m}$ are the unobservable factors of profits. Since Caixa is the only bank allowed to distribute the program, $\lambda_{i}$ is set to zero for other banks.

This configuration generates seven economically relevant parameters. $\alpha$ quantifies the extra profitability that comes from entering a municipality with higher GDP through higher market size for credit or new deposit accounts. $\lambda$ is the marginal monetary value that Caixa attributes to entering a municipality with more Bolsa Família beneficiaries. Another way to interpret the coefficient is that it represents how much profit Caixa is willing to abdicate to distribute benefits to one extra family.

The fixed cost $F$ associated with starting operations in a new market is useful to disentangle the operational costs of starting operations from the competition costs associated with the elasticities parameters $(\Gamma)$.

By allowing same-type competitors to affect profits differently than different-type competitors, the model generates four competition parameters: $\Gamma_{c c}$ and $\Gamma_{o o}$ are the crowding-out effect generated by one extra same-type branch in the market, while $\Gamma_{c o}$ and $\Gamma_{o c}$ are marginal inter-bank competition effects. Since the category Other Banks represents all banks except Caixa Econômica Federal, $\Gamma_{\text {oo }}$ actually aggregates effects between different commercial banks while $\Gamma_{c o}$ and $\Gamma_{o c}$ indicate whether Caixa competes for commercial 
banks profits.

\section{2}

\section{Equilibrium}

The agents play a simultaneous game to decide whether or not to enter each municipality. We need two conditions for a Nash Equilibrium to this game. First, branches that start operations in a market have positive profits. Otherwise, it would be profitable, given other agents' decisions, not to enter. Therefore, we must have:

$$
\Pi_{c m}(a, b)+\varepsilon_{c m} \geq 0 \quad \text { and } \quad \Pi_{o m}(a, b)+\varepsilon_{o m} \geq 0
$$

Second, by the same logic, branches that do not enter would have negative profits if they operated. Let $\Pi_{i m}(a, b)$ be type $i$ bank's observable profit when there are a Caixa's and $b$ Other Bank's in market $m$. Then, in a Nash Equilibrium, we must also have:

$$
\Pi_{c m}(a+1, b)+\varepsilon_{c m}<0 \quad \text { and } \quad \Pi_{o m}(a, b+1)+\varepsilon_{o m}<0
$$

To guarantee the existence of a Nash Equilibrium, we must make two assumptions:

Assumption 1: $\quad \Gamma_{c c}, \Gamma_{o o}, \Gamma_{c o}$, and $\Gamma_{o c}$ are strictly positive.

The first assumption means that any competitor that enters the market lowers the profits of all its competitors. It is reasonable since branches lose market share when there is a new participant in the market.

Assumption 2: $\lim _{x \rightarrow \infty} \Pi_{c m}(x, b)<0$ and $\lim _{y \rightarrow \infty} \Pi_{o m}(a, y)<0$, for every $a$ and $b$.

The second assumption states that, independently of the other type's decisions, there is a limit in the number of profitable branches that can be opened. Since the number of consumers is always finite, it makes sense always to exist a point where the costs of opening a new branch exceed its benefits.

Theorem 5.1 Under Assumption 1 and Assumption 2, a Nash Equilibrium for the game always exists, although it may not be unique.

Proof. First, fix a value $b=\bar{b}$. Since $\Pi_{c}(0, \bar{b})=0$, there always exists some value $a$ such that $\Pi_{c}(a, \bar{b}) \geq 0$. From Assumption 2 , there also always exists an $a$ such that $\Pi_{c}(a, \bar{b})<0$. From Assumption $1, \Pi_{c}(a, b)$ and $\Pi_{o}(a, b)$ are strictly decreasing in both $a$ and $b$. Therefore, there must be an $a^{*}$ such that $\Pi_{c}\left(a^{*}, \bar{b}\right) \geq 0$ and $\Pi_{c}\left(a^{*}+1, \bar{b}\right)<0$. Now, fix $a=a^{*}$. Using the same argument, 
there must exist a $b^{*}$ such that $\Pi_{c}\left(a^{*}, b^{*}\right) \geq 0$ and $\Pi_{c}\left(a^{*}, b^{*}+1\right)<0 .\left(a^{*}, b^{*}\right)$ is a Nash Equilibrium.

Figure 5.1: Simplified Model Equilibria

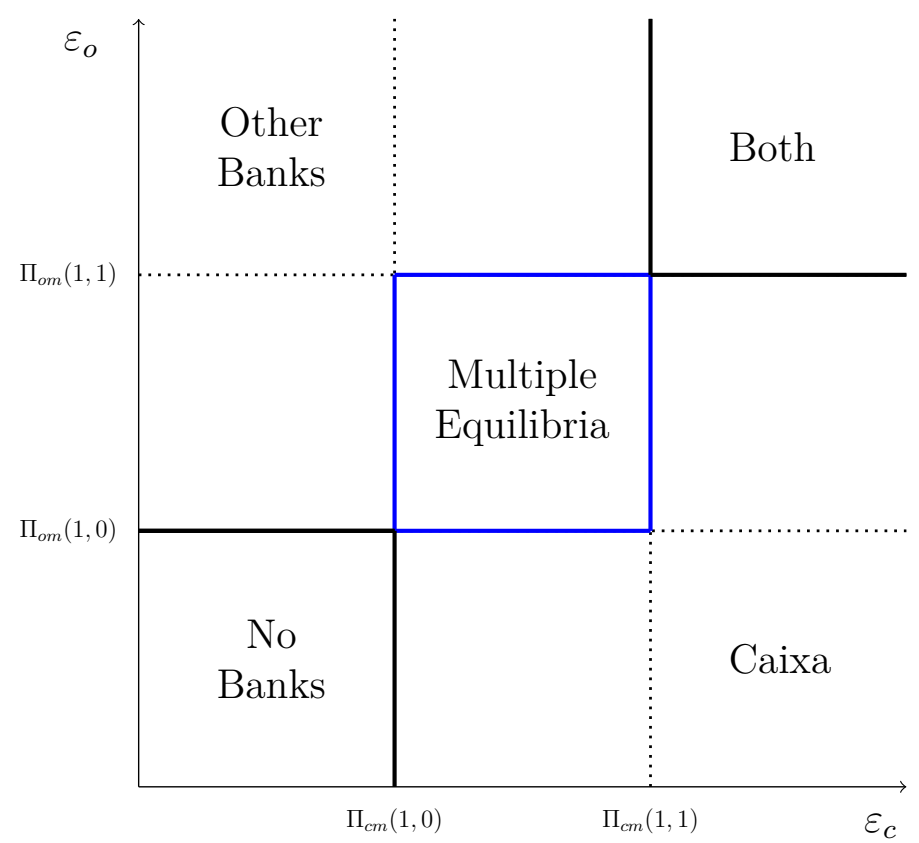

Notes: The Graph describes the parameters regions which generate each possible equilibrium, allowing the possibility of multiple equilibria. For didactic purposes, it is based on a simplified version of the model with the binary decision of entering or not each Municipality. A graph for the full model would give us the same intuition but would require a considerable amount of extra regions.

To give some intuition, Graph 5.1 illustrates the possible market outcomes in a simplified version of the model, where there is only one agent of each type. It shows that each branch will enter the market if its shock is favorable enough, given the parameters' values and other type's decisions. Changing parameters values would dislocate the line where each bank finds it profitable to enter the market.

To extend the graph to represent the full model, we would need to draw each of the $(N+1) * N$ horizontal straight lines $\Pi_{c}(a, b)$ and the $(N+1) * N$ lines $\Pi_{o}(a, b)$ for every combination of $a$ and $b$ from 0 to $N$ and order them, creating $2^{N+1}$ possible outcomes.

The multiple equilibria possibility arises because, in those regions, both agents find it profitable to enter the market if there are $N$ competitors, but not if there are $N+1$. Therefore, we could either observe that only Caixa enters or only Other Banks enter that market. This situation may cause some problems for estimating the model since the same parameters may predict two different market outcomes. To solve this problem, we need to impose one extra assumption: 
Assumption 3: $\quad \Gamma_{c c}>\Gamma_{c o}$ and $\Gamma_{o o}>\Gamma_{o c}$.

This assumption states that the impact of a new same-type competitor on profits is always larger than the impact of a different-type competitor. It is a reasonable condition since same-type branches provide the same services and usually have a closer consumer base than different-type competitors. It restricts the possible multiple equilibria to those in nearby regions where one extra Caixa branch or one extra Other Banks branch would find it profitable to enter the market if the other one decides not to enter but would not otherwise.

Now, it is possible to define an equilibrium selection mechanism. Defining that, in the case of multiple equilibria, the last branch to enter is the one which would have higher profits by operating, only one Nash Equilibrium is possible and the following extra inequalities hold:

$$
\begin{aligned}
& \text { Caixa enters if } \Pi_{c m}(a, b)+\varepsilon_{c m}>\Pi_{o m}(a-1, b+1)+\varepsilon_{o m} \quad \text { and, } \\
& \text { Other Banks enter if } \Pi_{o m}(a, b)+\varepsilon_{o m}>\Pi_{c m}(a+1, b-1)+\varepsilon_{c m}
\end{aligned}
$$

Figure 5.2: Simplified Model Equilibria, Imposing Selection Mechanism

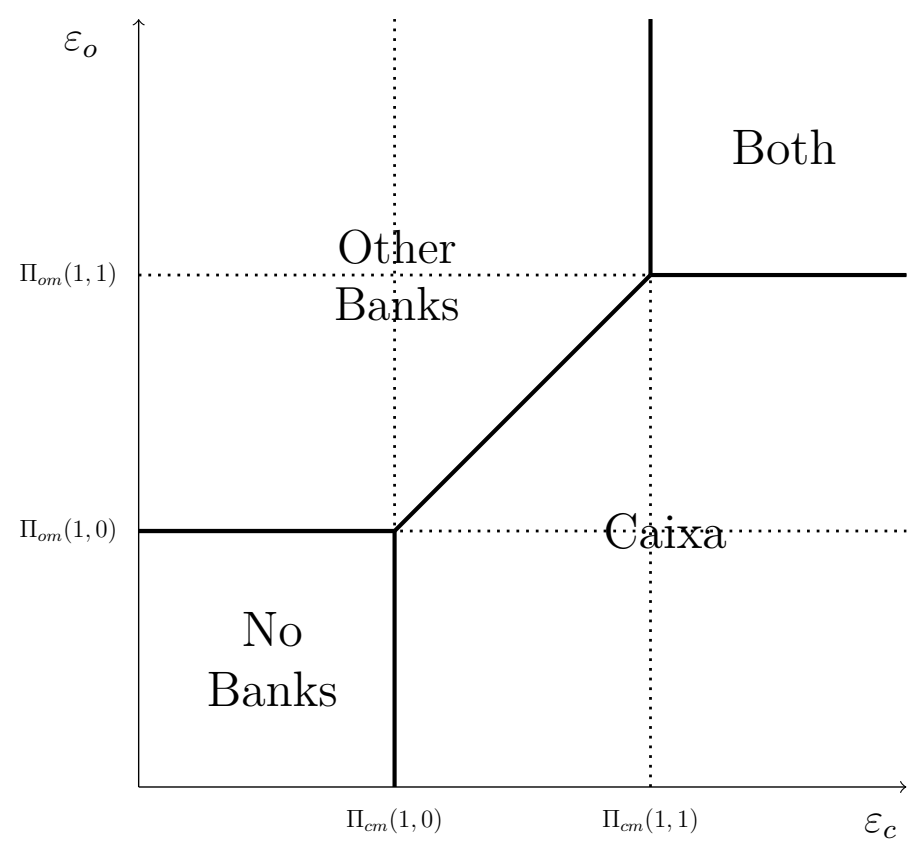

Notes: The Graph describes the parameters regions which generate each possible equilibrium, after we impose the selection mechanism that assumes the bank with higher profits operates when two equilibria are possible. For didactic purposes, it is based on a simplified version of the model with the binary decision of entering or not each Municipality. A graph for the full model would give us the same intuition but would require a considerable amount of extra regions.

The selection mechanism is illustrated in the simpler version of the model by Figure 5.2. The diagonal line that separates the region where Caixa and 
Other Banks enter is precisely the line where both types would have the same profit by operating. Rigorously, the line is still a region where multiple equilibria are possible. However, since it has measure zero, it should not cause any practical issues.

Even after imposing the selection mechanism, the model generates $2^{N+1}$ possible equilibrium outcomes, where $\mathrm{N}$ is the maximum number of agencies or banking correspondents. Considering that we observe 25,316 private banks once in our sample, computing the parameters for all the possible outcomes and regions in this model would be prohibitive. Therefore, we must define a cutoff $X$ such that markets that surpass this quantity will be included in the region "Xor more branches".

Table 5.2 reports the joint distribution of banks in Brazil to assist on the choice of $X$. The table's main point is to show that Caixa rarely has more than three branches in a market, while the other banks choose to keep expanding their operations, depending on the market's profitability. Therefore, this indicates that Caixa is indeed faced with different incentives than other banks and suggests extending the model up to 4 branches should be enough to characterize the economic environment.

Table 5.1: Joint Distribution of Banks in January 2004

\begin{tabular}{cccccccccccc}
\hline \hline & \multicolumn{110}{c}{ Number of Other Banks } \\
\cline { 2 - 13 } Number of Caixas & 0 & 1 & 2 & 3 & 4 & 5 & 6 & 7 & 8 & 9 & 10 \\
\hline 0 & 95 & 45 & 20 & 7 & 5 & 0 & 0 & 3 & 0 & 1 & 0 \\
1 & 1,987 & 1,180 & 515 & 216 & 112 & 50 & 43 & 16 & 12 & 8 & 4 \\
2 & 112 & 94 & 91 & 78 & 52 & 44 & 41 & 18 & 20 & 21 & 12 \\
3 & 5 & 1 & 1 & 9 & 18 & 19 & 22 & 12 & 19 & 13 & 12 \\
4 & 0 & 0 & 0 & 0 & 1 & 2 & 5 & 2 & 1 & 4 & 3 \\
5 & 0 & 0 & 0 & 1 & 0 & 1 & 1 & 1 & 0 & 0 & 1 \\
6 & 0 & 0 & 0 & 1 & 0 & 0 & 0 & 0 & 0 & 1 & 0 \\
7 & 0 & 0 & 0 & 0 & 0 & 0 & 0 & 0 & 0 & 1 & 0 \\
8 & 0 & 0 & 0 & 0 & 0 & 0 & 0 & 0 & 1 & 0 & 1 \\
9 & 0 & 0 & 0 & 0 & 2 & 0 & 0 & 1 & 0 & 0 & 0 \\
10 & 0 & 0 & 0 & 0 & 0 & 0 & 0 & 0 & 0 & 0 & 2 \\
\hline
\end{tabular}

Notes: Number of Caixa's branches are represented in the vertical-Axis while the number of other banks' branches are represented in the horizontal-axis. Both Agencies and Banking Correspondents were considered in the Table. For clarity purposes, joint distribution is reported only up to 10 branches, even tough some municipalities have more branches.

Given the problem's relatively high dimensionality, to estimate the model, I used a simulation-based approach. It consists of drawing random shocks $\left(\varepsilon_{c}, \varepsilon_{o}\right)$ from a known distribution and calculating the simulated equilibrium at each market for a given value of the parameters. Then, I compute the number of times the observed outcome in the data is equal to the simulated. This process is repeated several times for different values of the parameters. 
The estimated parameters are the ones that make the simulated configuration most similar to the actual data. The complete estimation algorithm is described in Appendix A.1.

\section{3}

\section{Estimates}

Model's estimated parameters are reported in Table 5.2 and Figure 5.3. Coefficients do not have a direct economic meaning since our profit function is not defined in a specific value unit. Instead, it is a multiple of the actual profit function in Reais $(R \$)$.

The $\alpha$ coefficient, which is the marginal value of entering a municipality with higher GDP, increased significantly between 2004 and 2008. The increase is probably related to the period's favorable macroeconomic scenario, which increased the demand for credit, as indicated by Figure 3.3. $\lambda$, in contrast, is considerably higher in the first years of the program when Caixa had to catch up with the Bolsa Familia program's expansion. However, because of the large standard errors associated with estimation, the null hypothesis that $\lambda=0$ cannot be rejected. Nevertheless, the counterfactual reported in the next section suggests that the coefficient is sufficient to cause a sizeable expansion of Caixa's operations in the period.

Table 5.2: Main Estimates of the Model

\begin{tabular}{ccccccccc}
\hline \hline Year & $\alpha$ & $\lambda$ & Ratio & $\mathrm{F}$ & $\Gamma_{c c}$ & $\Gamma_{c o}$ & $\Gamma_{o o}$ & $\Gamma_{o c}$ \\
\hline 2004 & $3.72 \mathrm{e}-08$ & $1.48 \mathrm{e}-05$ & \multirow{2}{*}{$3.98 \mathrm{e}+02$} & $6.29 \mathrm{e}-04$ & $9.77 \mathrm{e}-02$ & $1.00 \mathrm{e}-04$ & $1.28 \mathrm{e}-03$ & $1.21 \mathrm{e}-04$ \\
& $(2.14 \mathrm{e}-07)$ & $(2.96 \mathrm{e}-05)$ & & $(1.30 \mathrm{e}-03)$ & $(2.20 \mathrm{e}-03)$ & $(3.64 \mathrm{e}-04)$ & $(2.14 \mathrm{e}-03)$ & $(2.77 \mathrm{e}-04)$ \\
2005 & $4.06 \mathrm{e}-08$ & $1.76 \mathrm{e}-05$ & $4.34 \mathrm{e}+02$ & $7.63 \mathrm{e}-04$ & $9.74 \mathrm{e}-02$ & $5.51 \mathrm{e}-05$ & $1.51 \mathrm{e}-03$ & $7.07 \mathrm{e}-05$ \\
& $(2.55 \mathrm{e}-07)$ & $(2.93 \mathrm{e}-05)$ & & $(1.39 \mathrm{e}-03)$ & $(2.28 \mathrm{e}-03)$ & $(1.57 \mathrm{e}-04)$ & $(2.28 \mathrm{e}-03)$ & $(1.96 \mathrm{e}-04)$ \\
2006 & $6.51 \mathrm{e}-08$ & $1.18 \mathrm{e}-05$ & $1.82 \mathrm{e}+02$ & $6.62 \mathrm{e}-04$ & $9.65 \mathrm{e}-02$ & $1.14 \mathrm{e}-04$ & $2.41 \mathrm{e}-03$ & $5.10 \mathrm{e}-05$ \\
& $(3.00 \mathrm{e}-07)$ & $(2.35 \mathrm{e}-05)$ & & $(1.44 \mathrm{e}-03)$ & $(3.34 \mathrm{e}-03)$ & $(3.98 \mathrm{e}-04)$ & $(3.41 \mathrm{e}-03)$ & $(2.64 \mathrm{e}-04)$ \\
2007 & $6.33 \mathrm{e}-08$ & $5.12 \mathrm{e}-06$ & $8.09 \mathrm{e}+01$ & $9.66 \mathrm{e}-04$ & $9.53 \mathrm{e}-02$ & $6.52 \mathrm{e}-05$ & $3.29 \mathrm{e}-03$ & $1.44 \mathrm{e}-04$ \\
& $(3.65 \mathrm{e}-07)$ & $(1.80 \mathrm{e}-05)$ & & $(1.82 \mathrm{e}-03)$ & $(4.56 \mathrm{e}-03)$ & $(2.59 \mathrm{e}-04)$ & $(4.72 \mathrm{e}-03)$ & $(5.06 \mathrm{e}-04)$ \\
2008 & $1.10 \mathrm{e}-07$ & $8.02 \mathrm{e}-06$ & $7.30 \mathrm{e}+01$ & $1.18 \mathrm{e}-03$ & $9.32 \mathrm{e}-02$ & $9.69 \mathrm{e}-05$ & $5.06 \mathrm{e}-03$ & $7.82 \mathrm{e}-05$ \\
& $(3.26 \mathrm{e}-07)$ & $(3.15 \mathrm{e}-05)$ & & $(2.52 \mathrm{e}-03)$ & $(6.03 \mathrm{e}-03)$ & $(3.23 \mathrm{e}-04)$ & $(6.41 \mathrm{e}-03)$ & $(2.42 \mathrm{e}-04)$ \\
2009 & $3.88 \mathrm{e}-08$ & $1.06 \mathrm{e}-05$ & $2.74 \mathrm{e}+02$ & $1.01 \mathrm{e}-03$ & $9.06 \mathrm{e}-02$ & $1.04 \mathrm{e}-04$ & $7.88 \mathrm{e}-03$ & $1.33 \mathrm{e}-04$ \\
& $(4.27 \mathrm{e}-07)$ & $(2.80 \mathrm{e}-05)$ & & $(2.06 \mathrm{e}-03)$ & $(9.28 \mathrm{e}-03)$ & $(2.87 \mathrm{e}-04)$ & $(9.34 \mathrm{e}-03)$ & $(5.14 \mathrm{e}-04)$ \\
2010 & $1.33 \mathrm{e}-07$ & $1.28 \mathrm{e}-05$ & $9.62 \mathrm{e}+01$ & $2.27 \mathrm{e}-04$ & $9.00 \mathrm{e}-02$ & $6.33 \mathrm{e}-05$ & $9.44 \mathrm{e}-03$ & $8.34 \mathrm{e}-05$ \\
& $(3.52 \mathrm{e}-07)$ & $(2.65 \mathrm{e}-05)$ & & $(5.81 \mathrm{e}-04)$ & $(1.06 \mathrm{e}-02)$ & $(1.62 \mathrm{e}-04)$ & $(1.07 \mathrm{e}-02)$ & $(3.16 \mathrm{e}-04)$ \\
\hline
\end{tabular}

Notes: Ratio is not directly estimated from the model. It is defined as $\frac{\lambda}{\alpha}$. Estimates for all years are available at the Appendix.

To facilitate interpretation, the variable Ratio $=\frac{\lambda}{\alpha}$ is reported. This coefficient tells us, given market sizes and competitive setups, how much Caixa is willing to abdicate entering a more lucrative market (with higher GDP per capita) to attend a city with more Bolsa Família beneficiaries. For instance, the Ratio coefficient in 2004 means that Caixa is indifferent between 
entering a municipality with 398 fewer Reais in GDP per capita and entering a municipality with one extra percent of Bolsa Família beneficiaries.

The Ratio is higher in the first years of the Bolsa Familia program but remains considerably high until 2010. The result is compatible with our hypothesis that Caixa was interested in expanding its operations in the first years of the program to guarantee access to all beneficiaries.

Figure 5.3: Estimated Coefficients from 2004 to 2009.
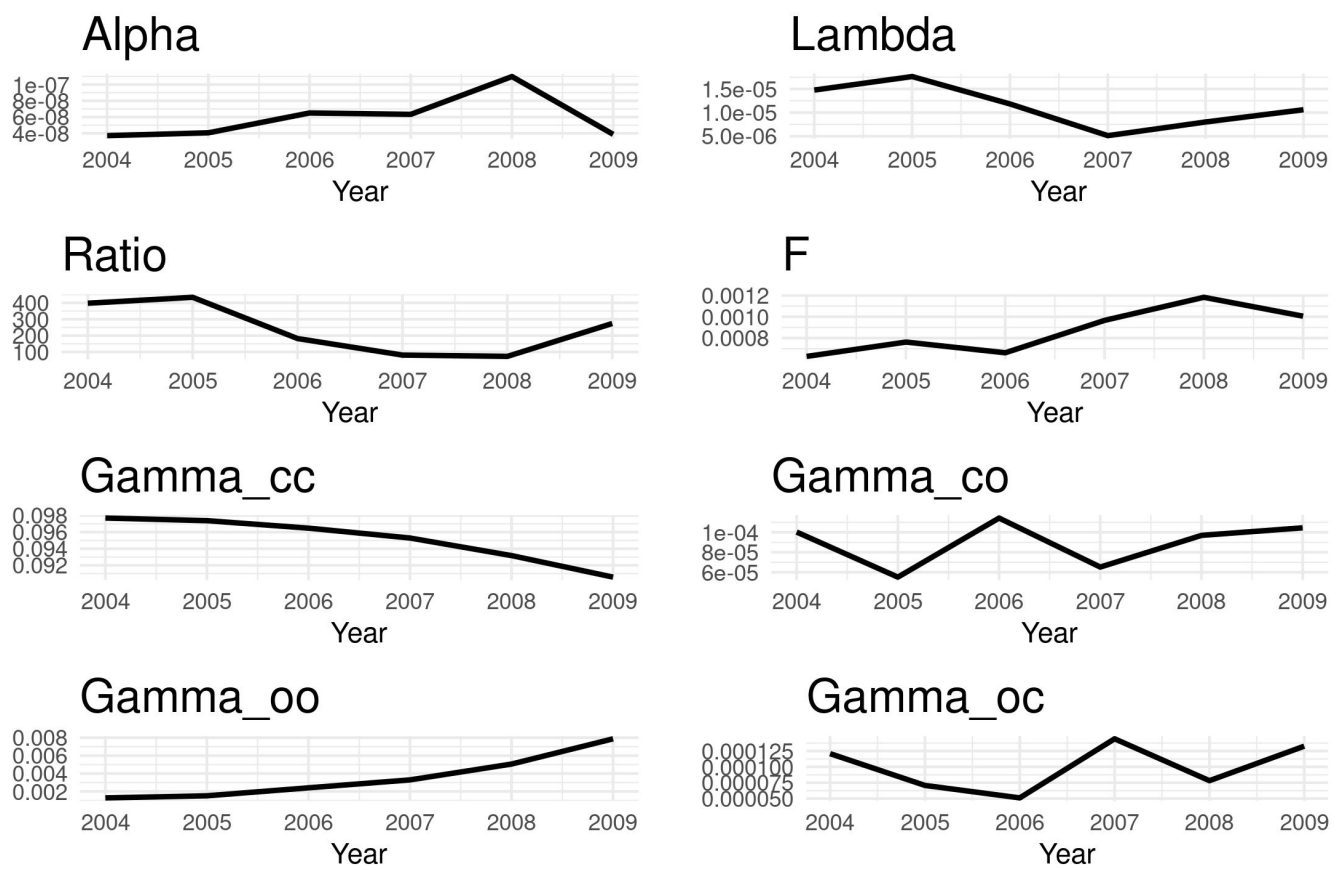

Notes: Ratio is not directly estimated from the model. It is defined as $\frac{\lambda}{\alpha}$. Estimates for all years are available at the Appendix.

The same-type elasticities presented contrasting behaviors: while $\Gamma_{o o}$ more than quadrupled from 2004 to 2009, indicating increasing competition in the credit market, $\Gamma_{c c}$ slowly but regularly decreased. Still, $\Gamma_{c c}$ remained almost ten times bigger than $\Gamma_{o o}$. This difference suggests that, to Caixa, it is much less profitable to open additional branches in a market once it already covers it, perhaps because the extra branch does not improve Bolsa Familia's distribution as much as the first branch (see Table 6.4).

The different-type elasticities did not present a very discernible pattern over the years, although their magnitudes are much smaller than the sametype elasticities. Caixa does not seem to compete with commercial banks and vice-versa. Results are similar to Coelho et al. (2013). Target consumers being inherently different or Caixa's focus on the Bolsa Família program could explain this.

The fixed cost $(F)$ coefficient remained stable in the first years but increased steadily after 2006, probably due to increased logistics costs. It is also 
much smaller than the same-type elasticities, indicating that the main costs governing branches' decisions are related to market structure and competition.

One limitation of the model is that, due to computational restrictions, only 100 samples were bootstrapped for each estimation, generating higher standard error than ideal. Therefore, the estimates may not be so precise.

Since banking coverage is almost universal after 2009, the data for these years do not have enough cross-section variation for the model to identify its parameters, and the estimations are imprecise. Therefore, I choose to omit them from the text, but estimates for all years from 2004 to 2017 are available in Appendix A.3.

\section{4}

\section{Counterfactual Analysis}

The model's estimation allows us to create a banking coverage counterfactual in Brazil for each year in our sample. The counterfactual shows how would Brazilian banking coverage be if the Bolsa Família program did not exist (or if Caixa did not care about the program's distribution). Therefore, counterfactual municipalities are defined as those covered by Caixa in the data, which would not be if we set $\lambda$ to zero. Using this setting, I simulate counterfactual profits and outcomes in each municipality, generating a new equilibrium banking coverage.

Figure 5.4 reports the difference between the actual and predicted total of municipalities with bank coverage in Brazil between 2004 and 2009. It shows that the Bolsa Familia program accelerated banking coverage in Brazil, with more than 1000 municipalities being covered in 2005 only because Caixa was preoccupied with distributing the program.

The model generates a relatively small number of counterfactual municipalities between 2006 and 2008 due to the smaller $\lambda$ in these years. These oscillations in the counterfactual come from imprecision in estimating the parameters caused by the small number of bootstraps. Nevertheless, counterfactual coverage remains positive in all years of our sample.

Although banking coverage would most likely expand in Brazil even in the absence of the CCT program, the program accelerated this process and was probably responsible for externalities in bancarization by anticipating banking presence in remote areas. One possible extension of this research, if bancarization data were publicly available, would be to investigate trends in the access to financial services of municipalities in the counterfactual and relate them to Caixa's coverage.

Figure 5.5 reports counterfactual municipalities in 2004, that is, the 
Figure 5.4: Counterfactual Banking Coverage

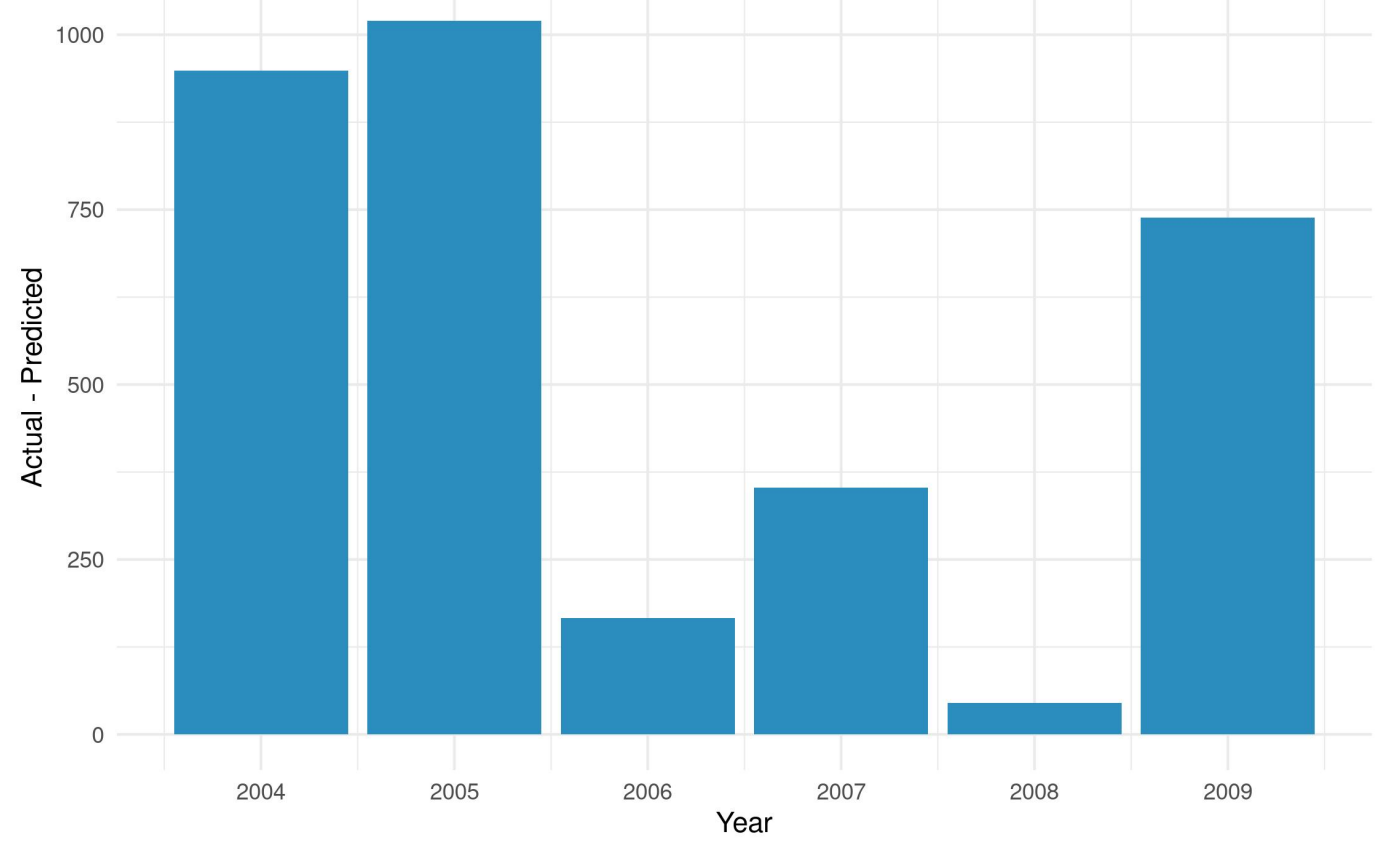

Notes: Counterfactual Municipalities are the Municipalities which are covered by Caixa but would not be in the Counterfactual where $\lambda$ is forced to zero, that is, if Caixa did not confer any monetary value to distributing benefits to Bolsa Família Beneficiaries.

municipalities that were covered only by Caixa but would not be if $\lambda=0$. Coverage is concentrated in municipalities in poor regions such as the interior of the Piaui and Tocantins states and the North of Minas Gerais.

Counterintuitively, few municipalities from the Northern region of Brazil are included in the counterfactual. It may seem strange since it is a region with lots of poor municipalities and a high percentage of Bolsa Família beneficiaries (Figure 3.5). However, the Northern municipalities are, on average, territorially extensive municipalities that, even though they have a small population density and low urbanization rates, have relatively high populations. Indeed, the average population for Northern municipalities in 2004 was 33,995, the secondhighest for any Brazilian Region.

Thus, the model considers that it is lucrative to cover these markets, even if the Bolsa Familia program did not exist. It might suggest that the counterfactual results are being underestimated since a relatively high percentage of the population lives in remote rural areas and would not have access to banking services even if it opened in the main municipality district.

Table 5.3 compares municipalities in the counterfactual with municipalities that would be covered by some bank in the counterfactual and are covered in the data.

In all years of our sample, Caixa enters municipalities with a smaller 
Figure 5.5: Counterfactual Banking Coverage in 2004

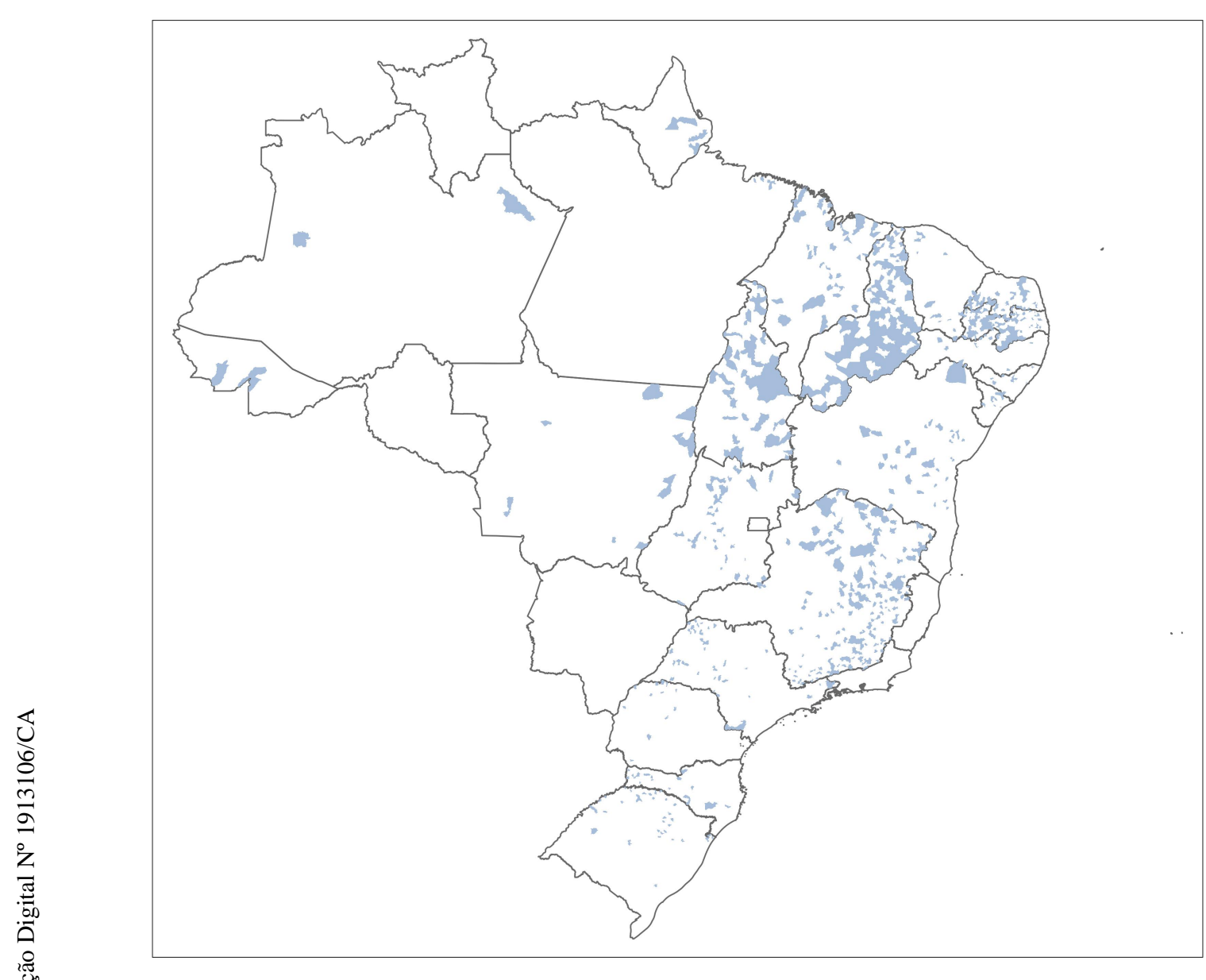

Notes: Counterfactual Municipalities are the Municipalities which are covered by Caixa but would not be in the Counterfactual where $\lambda$ is forced to zero, that is, if Caixa did not confer any monetary value to distributing benefits to Bolsa Família Beneficiaries.

population and GDP per capita and a higher proportion of Bolsa Familia beneficiaries. Comparison of the groups in 2004 makes the contrast clear: Caixa's counterfactual municipalities have an average population, GDP per capita and percentage of Bolsa Família beneficiaries of 4,342, 3,242 and 5.1, while covered municipalities had 39,109, 7,915, and 2.9, respectively. This contrast remains in the following years. 
Table 5.3: Characteristics of Counterfactual Municipalities

\begin{tabular}{|c|c|c|c|c|c|c|c|c|}
\hline \multirow[b]{2}{*}{ Year } & \multicolumn{4}{|c|}{ Counterfactual Municipalities } & \multicolumn{4}{|c|}{ Covered Municipalities } \\
\hline & Population & GDP per Capita & Beneficiaries & $\mathrm{N}$ & Population & GDP per Capita & Beneficiaries & $\mathrm{N}$ \\
\hline 2004 & $\begin{array}{c}4,342 \\
(2,090)\end{array}$ & $\begin{array}{c}3.242 \\
(1.765)\end{array}$ & $\begin{array}{c}0.051 \\
(0.037)\end{array}$ & 949 & $\begin{array}{c}39,109 \\
(215,885)\end{array}$ & $\begin{array}{l}7.915 \\
(9.33)\end{array}$ & $\begin{array}{c}0.029 \\
(0.025)\end{array}$ & 4,516 \\
\hline 2005 & $\begin{array}{c}4,234 \\
(2,105)\end{array}$ & $\begin{array}{c}3.754 \\
(2.029)\end{array}$ & $\begin{array}{c}0.074 \\
(0.039)\end{array}$ & 1,020 & $\begin{array}{c}40,162 \\
(219,409)\end{array}$ & $\begin{array}{l}8.198 \\
(9.838)\end{array}$ & $\begin{array}{c}0.049 \\
(0.031)\end{array}$ & 4,464 \\
\hline 2006 & $\begin{array}{c}2,881 \\
(1,108)\end{array}$ & $\begin{array}{c}3.371 \\
(1.315)\end{array}$ & $\begin{array}{c}0.111 \\
(0.039)\end{array}$ & 166 & $\begin{array}{c}35,107 \\
(204,171)\end{array}$ & $\begin{array}{l}8.225 \\
(9.708)\end{array}$ & $\begin{array}{c}0.069 \\
(0.038)\end{array}$ & 5,285 \\
\hline 2007 & $\begin{array}{c}3,429 \\
(1,339)\end{array}$ & $\begin{array}{c}3.929 \\
(1.609)\end{array}$ & $\begin{array}{c}0.129 \\
(0.039)\end{array}$ & 353 & $\begin{array}{c}35,687 \\
(206,345)\end{array}$ & $\begin{array}{c}9.566 \\
(11.089)\end{array}$ & $\begin{array}{l}0.084 \\
(0.044)\end{array}$ & 5,102 \\
\hline 2008 & $\begin{array}{l}2,293 \\
(801)\end{array}$ & $\begin{array}{c}4.549 \\
(1.851)\end{array}$ & $\begin{array}{c}0.135 \\
(0.037)\end{array}$ & 45 & $\begin{array}{c}35,085 \\
(203,778)\end{array}$ & $\begin{array}{c}10.39 \\
(12.207)\end{array}$ & $\begin{array}{c}0.084 \\
(0.045)\end{array}$ & 5,380 \\
\hline 2009 & $\begin{array}{c}4,045 \\
(1,761)\end{array}$ & $\begin{array}{c}5.566 \\
(2.589)\end{array}$ & $\begin{array}{l}0.111 \\
(0.04)\end{array}$ & 739 & $\begin{array}{c}39,759 \\
(218,528)\end{array}$ & $\begin{array}{c}11.698 \\
(12.136)\end{array}$ & $\begin{array}{c}0.08 \\
(0.044)\end{array}$ & 4,727 \\
\hline
\end{tabular}

Notes: Counterfactual Municipalities are the Municipalities which are covered by Caixa but would not be in the Counterfactual where $\lambda$ is forced to zero, that is, if Caixa did not confer any monetary value to distributing benefits to Bolsa Família Beneficiaries. Covered Municipalities are the Municipalities which are both covered in a given year and would still be covered in its counterfactual.

Results reveal Caixa's efforts to expand its operations to remote and poor regions which, although not profitable to other Banks, have a high percentage of Bolsa Família beneficiaries. 


\section{6 \\ Reduced Form Analysis}

\section{1}

\section{Empirical Strategy}

This section presents evidence that many vulnerable people can only effectively access cash transfer policies when there is a Caixa agency or banking correspondent in the municipality. Since CCTs are focused on the poor and extremely poor, often with small children, families may face difficulties to travel great distances, and accessibility concerns may be of great importance. As explained in Section 1, benefits from Bolsa Família are canceled if not withdrawn in 6 months. I will investigate if cancellations rise when Caixa leaves a municipality and, conversely, if cancellations decline when Caixa enters.

The natural setting for the analysis is a Differences-in-Differences model with staggered adoption. There is booming literature in Econometrics that proposes new and improved procedures for estimating this type of model, systematized and summarized by Baker et al. (2021). Unfortunately, in this case, there are units that both start and stop being treated (Caixa opens and closes branches) along the sample, which do not allow the use of the main suggested specifications and tests by Athey \& Imbens (2018), Goodman-Bacon (2018) and Callaway \& Sant'Anna (2020), all designed with the assumption that a treated unit will remain treated for the duration of the analysis.

Therefore, my main specification is a simple Differences-in-Differences approach with variation in treatment timing, noting that the effect's interpretation is not as straightforward as one would wish. The final estimate will be a weighted average of several comparisons between treated and not treated units along different periods, possibly making some of the treated units have negative weights in the final reported coefficient. Model's identification essentially relies on Caixa's Coverage's timing and its association with a decline in the number of canceled benefits.

The estimated equation is given by:

$$
Y_{i t}=\beta_{0}+\beta_{1} \text { Caixa }_{i t}+\beta_{2} X_{i t}+\phi_{i}+\eta_{t}+\varepsilon_{i t}
$$

Where $Y_{i t}$ is the number of Cancelled Benefits per thousand beneficiaries, Caixa ${ }_{i t}$ indicates Caixa's Agency or Banking correspondent coverage in month 
$t$ at municipality $i, X_{i t}$ is the vector of covariates $(\log (\mathrm{GDP}$ per Capita) and $\log ($ Population $)), \phi_{i}$ is a municipality fixed effect, $\eta_{t}$ is a month-year fixed effect, and $\varepsilon_{i t}$ is the error term. the coefficient of interest is $\beta_{1}$. This setting makes it explicit that banks are allowed to enter and leave municipalities at any period, allowing control units to become treated and vice-versa. It is an essential feature of our model because the entrance and exit decisions constitute a significant study aspect.

There may exist concerns regarding Caixa's coverage exogeneity. As established in the previous section, Caixa's coverage decisions are partly motivated by the distribution of the $\mathrm{PBF}$ program, making the coverage regressor possibly endogenous to the number of canceled benefits. There is no simple way to solve this identification problem. The paper tests several different specifications and placebo tests to increase confidence in the effects, but some inherent uncertainty is associated with the identification.

\section{2}

\section{Main Results}

Table 6.1 presents the main results. I am mostly interested in Panel A, which measures the impact of Caixa's coverage on the number of canceled benefits per thousand beneficiaries. The first column, which reports the simplest regression with no controls and fixed effects, has a negative coefficient that is significant at the $10 \%$ level. The other three columns, which add $\log$ (GDP per Capita) and $\log$ (Population) controls, municipality fixed effects and time fixed effects, respectively, all report negative coefficients which are significant at the $1 \%$ level.

Our main specification described by Equation 6-1, is reported in Column 4. It indicates that Caixa's coverage, on average, prevents 1.980 canceled benefits from the Bolsa Familia program for every thousand beneficiaries. Considering the dependent variable's sample mean is 20, Caixa's coverage accounts for a decrease of $9.9 \%$ in the number of canceled benefits.

To increase confidence in the results, I also estimated the same equations, using Banco do Brasil and Privates Banks' coverage - banks that do not distribute Bolsa Família benefits - as our dependent variables. Since Caixa is the only bank authorized to pay the benefits, we would expect that other banks' coverage does not affect the program. Estimates are reported in Panel B and $\mathrm{C}$ of Table 6.1. In both panels, some coefficients are significant at $1 \%$ but are not robust, varying between positive and negative and losing significance, depending on the specification. No panel can replicate the result of negative and significant coefficients in Column 4, which controls for the other primary 
Table 6.1: Regressions linking Caixa Econômica Federal's Coverage to Bolsa Família's Cancelled Benefits.

Dependent Variable: Cancellations per 1000
(1)
$(2)$
(3)

\section{Panel A: Caixa Econômica Federal}
Caixa Coverage
$-0.687^{*}$
$-1.048^{* * *}$
$-4.949^{* * *}-1.980^{* * *}$
(0.356)
(0.384)
(0.673)
$(0.563)$

\section{Panel B: Banco do Brasil}

BB Coverage

$\begin{array}{cccc}-1.125^{* * *} & 1.937^{* * *} & -1.436 & -0.239 \\ (0.304) & (0.334) & (0.945) & (0.790)\end{array}$

\section{Panel C: Private Banks}

Private Coverage

$$
-3.053^{*}
$$

\begin{tabular}{lcccc}
\hline Municipality Fixed Effects & No & No & Yes & Yes \\
Time Fixed Effects & No & No & No & Yes \\
Controls & No & Yes & Yes & Yes \\
Observations & 388,786 & 325,555 & 325,555 & 325,555 \\
Mean of Dependent Variable & 20.8 & 20.0 & 20.0 & 20.0 \\
\hline
\end{tabular}

Coverage is defined as the presence of at least one Agency or Banking Correspondent in the municipality. Standard errors in parenthesis, clustered at the municipality level. Every regression on each column has the same number of observations. Controls used are $\log \left(\right.$ GDP per Capita) and $\log$ (Population). ${ }^{*} p<0.1 ;{ }^{* *} p<0.05$; *** $p<0.01$.

sources of confounding variation.

Since the number of observations is high, some significant coefficients are expected, even though they disappear in some specifications. Because Panel A is the only robust set of regressions, there is increased credibility to the hypothesis that Caixa's coverage of the municipality matters for access to the Bolsa Familia program.

The relevance of the time fixed effects can be noted by comparing the magnitude of Columns 3 and 4 from Panel A. The steep decline in the magnitude of the effect suggests that there are also relevant variables such as the macroeconomic environment or federal government priorities that significantly affect the number of canceled benefits.

There is a reduction in the sample size of 63,231 observations from the 
first to the second columns because municipal GDP data from 2019 is still not available in Brazil. It may be an explanation for the smaller effects in the first column. Cancellations per thousand beneficiaries are much higher in 2019 in all regions, probably due to the new government's different priorities. It may dilute the effect of Caixa's coverage.

These results suggest that, when there is no bank in the municipality, some families cannot afford to travel to the nearest municipality with an authorized bank, resulting in lost access to the CCT program. The inability to withdraw benefits is not surprising since, in our sample, we registered families that needed to travel more than 200 Kilometers to access their benefits. Also, beneficiaries are families below the poverty line which have small kids in their household. These families would need to lose a day's job and find childcare to travel to the nearest agency, and sometimes the bus ticket may cost more than the actual benefits they are entitled to receive.

Banking infrastructure is, therefore, a relevant aspect for access to CCTs in developing countries. It may be trivial in developed economies, but accessibility concerns remain an issue that needs to be addressed when implementing programs directed to low-income families.

\section{3}

\section{Event Study}

Another possible setup to evaluate our framework is the Event Study specification. It allows us to see the intervention dynamics and verify even further that the investigated hypothesis holds in other settings. Ideally, the specification would follow Sun \& Abraham (2020), with a saturated model interacted with cohort dummies. Unfortunately, I cannot include all leads and lags in our estimation since, in our sample, Caixa's is seldom absent of a municipality for more than four months. It happens because we only have Cancellation data from 2014 onwards when Caixa's coverage is already considerable.

The estimation of the Sun \& Abraham (2020) method would be useful to certify that we are using the appropriate model and to allow us to estimate what happens after six months of Caixa's entrance, which is the limit for withdrawal of benefits defined by law. For that, we would need the data on canceled benefits since 2004, which are not consolidated at the Ministério de Desenvolvimento Social (MDS).

Considering this limitation, the estimated equation is given by:

$$
Y_{i p}=\beta_{0}+\sum_{\substack{-6 \leq p \leq 4, p \neq-1}} \beta_{1 p} \text { Caixa }_{i p}+\beta_{2} X_{i p}+\phi_{i}+\eta_{p}+\varepsilon_{i p}
$$


Period $p$ is defined as the distance in months to Caixa's entrance in the municipality, with negative values indicating that Caixa is yet to open its branch. $Y_{i p}$ is the number of Cancelled Benefits per thousand beneficiaries, Caixa $_{i p}$ indicates Caixa's Agency or Banking correspondent coverage in period $p$ at municipality $i, X_{i t}$ is the vector of covariates ( $\log$ (GDP per Capita) and $\log ($ Population $)), \phi_{i}$ is a municipality fixed effect, $\eta_{t}$ is a month-year fixed effect, and $\varepsilon_{i t}$ is the error term. the coefficient of interest are $\beta_{1 p}$.

This specification is particularly useful to verify if there is any anticipation behavior and if the effects are lasting. Anticipating behavior would undermine the central hypothesis since it is not compatible with access problems. Also, understanding the duration of the effect can give better insight into what happens at uncovered municipalities.

Estimated coefficients are reported in Figure 6.3. The graph shows that cancellations decline right after Caixa arrives at a given municipality, and there is no anticipation. Results are compatible with the theory that cancellations are mainly due to difficulties of access generated by Caixa's distance from families.

Figure 6.1: Event Study Specification

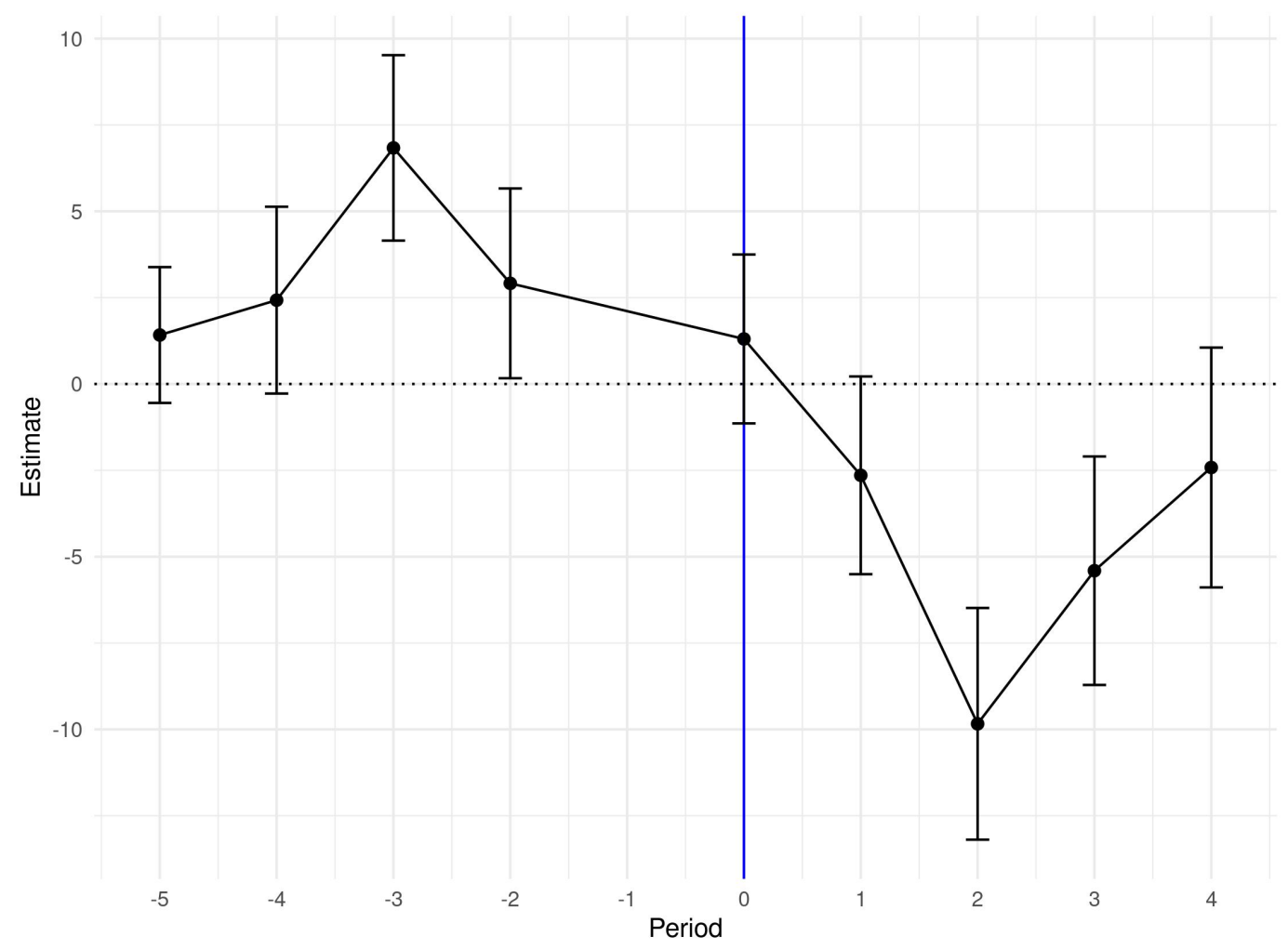

Notes: Confidence Interval of 95\%. Coverage is defined as the presence of at least one Agency or Banking Correspondent in the municipality. Standard errors clustered at the municipality level. Controls used are $\log (\mathrm{GDP}$ per Capita) and $\log$ (Population).

Also, effects tend to get smaller after the peak, two to three months 
after Caixa enters the municipality. It suggests a stock of beneficiaries cannot withdraw their benefits and get canceled early, while the other beneficiaries have fewer access problems. The main problem in this scenario is that precisely the most impoverished and vulnerable families, which are the policy's focus, are unable to access the program when there is no banking coverage.

Reported effects are bigger than those from the main results section, especially during the second and third months. It suggests that a reasonable number of families had not cashed out their benefits for months before Caixa's coverage since benefits can only be canceled after six months without withdrawals. It would be a difficult phenomenon to justify in normal circumstances because families with such levels of income are rarely able to save money and could never afford to leave their benefits at their accounts for several months. However, the hypothesis of access difficulties can easily justify this behavior: families do not withdraw because they cannot do so, and banking infrastructure is required for full access to the program.

To extend this analysis, we would need the complete data on cancellations. If I could analyze the period where Caixa had a smaller coverage, I would be able to compare the municipalities for up to six months after Caixa enters the municipality, allowing a complete assessment of the coverage effects. Nevertheless, existing data already indicates that access is indeed a problem in developing countries and should be a relevant variable when implementing policy.

\section{4 \\ Robustness}

As a first robustness exercise, I replicated the regressions estimated in Table 6.1 but changed the main regressor to Banks (or banking Correspondents) by ten thousand inhabitants. I use the same main specification indicated in Equation 6-1.

Table 6.4 reports the estimates. Panel A's estimates are all significant at the $1 \%$ level, which corroborates the hypothesis that Caixa's coverage is relevant for the access of the Bolsa Familia program.

Panel B and Panel C also remain not robust. Even though all estimates are significant at the $1 \%$ level, coefficients oscillate between positive and negative and are smaller than those of Panel A. Again; the high significance can be justified by the high number of observations in the regressions.

Compared to the main regressions, the effects are smaller. It happens because, conceptually, we measure something different. Instead of evaluating the impact of Caixa's coverage, we measure the effect that one more Caixa's 
agency or banking correspondent in the municipality has on the number of canceled benefits per thousand beneficiaries. Smaller effects indicate that the first Caixa branch to enter the municipality is the one that matters for access to benefits, with the other branches diluting the effect and making the coefficient smaller.

Table 6.2: Regressions linking Caixa's Agencies per 10 Thousand to Bolsa Família's Cancelled Benefits.

Dependent Variable: Cancellations per 1000
(1)
(2)
(3)
(4)

\section{Panel A: Caixa Econômica Federal}

Caixa per 10 Thousand

$$
\begin{array}{cccc}
-1.728^{* * *} & -0.525^{* * *} & -1.252^{* * *} & -0.288^{* * *} \\
(0.026) & (0.032) & (0.082) & (0.070)
\end{array}
$$

\section{Panel B: Banco do Brasil}
BB per 10 Thousand
$0.980^{* * *}$
$0.307^{* * *}$
$-0.157^{* * *}-0.205^{* * *}$
$(0.018)$
$(0.022)$
$(0.053)$
(0.046)

\section{Panel C: Private Banks}

Private Banks per 10 Thousand
$0.602^{* * *}$
$0.253^{* * *}$
$-0.180^{* * *}-0.044^{* * *}$
$(0.018)$
$(0.016)$
$(0.006)$
$(0.007)$

\begin{tabular}{lcccc}
\hline Municipality Fixed Effects & No & No & Yes & Yes \\
Time Fixed Effects & No & No & No & Yes \\
Controls & No & Yes & Yes & Yes \\
Observations & 388,786 & 325,555 & 325,555 & 325,555 \\
Mean of Dependent Variable & 20.8 & 20.0 & 20.0 & 20.0 \\
\hline
\end{tabular}

Coverage is defined as the presence of at least one Agency or Banking Correspondent in the municipality. Standard errors in parenthesis, clustered at the municipality level. Every regression on each column has the same number of observations. Controls used are $\log \left(\right.$ GDP per Capita) and $\log$ (Population). ${ }^{*} p<0.1 ;{ }^{* *} p<0.05 ;{ }^{* * *} p<0.01$.

In the preferred specification, one marginal Caixa agency or banking correspondent decreases cancellations by $1.44 \%$, which contributes to the story that the first agency is the most important and that the difficulty in access is effectively the capacity to travel to the nearest municipality to withdraw the benefits. It means that, for most municipalities, one agency should be enough to guarantee the proper distribution of benefits.

As a second robustness exercise, I estimated the same differences-indifferences model, changing the main regressor to the nearest bank's distance 
in Kilometers. Again, I use the same main specification indicated in Equation 6-1.

Table 6.4 reports the estimated coefficients. Contrary to previous estimates, Panel A's effects are not robust. The interpretation of these results is that the marginal effect on cancellations per 1000 beneficiaries of a higher distance to the nearest Caixa branch is zero. The only regression that reports results that would be intuitive is Column 3, which indicates that one more Kilometer to the nearest Caixa would increase cancellations by $0.36 \%$. However, we cannot infer that this effect is different from zero.

Panel B and C are also not robust and present similar patterns to Panel A. It indicates that there is probably no effect of Distance on Cancellations, despite one significant estimate.

Table 6.3: Regressions linking Distance to the Nearest Caixa Econômica Federal to Bolsa Família's Cancelled Benefits.

Dependent Variable: Cancellations per 1000

(1)

(2)

(3)

\section{Panel A: Caixa Econômica Federal \\ Distance to Caixa

$\begin{array}{cccc}-0.037^{* * *} & -0.007 & 0.071^{* * *} & 0.017 \\ (0.012) & (0.012) & (0.020) & (0.017)\end{array}$

\section{Panel B: Banco do Brasil}

Distance to BB

$$
\begin{array}{cccc}
-0.074^{* * *} & -0.164^{* * *} & 0.067 & -0.007 \\
(0.015) & (0.016) & (0.047) & (0.039)
\end{array}
$$

\section{Panel C: Private Banks}

Distance to Private Bank

$0.145^{*} \quad-0.111$

0.005

0.001

$(0.079)$

$(0.093)$

$(0.108)$

$(0.090)$

\begin{tabular}{lcccc}
\hline Municipality Fixed Effects & No & No & Yes & Yes \\
Time Fixed Effects & No & No & No & Yes \\
Controls & No & Yes & Yes & Yes \\
Observations & 388,786 & 325,555 & 325,555 & 325,555 \\
Mean of Dependent Variable & 20.8 & 20.0 & 20.0 & 20.0 \\
\hline
\end{tabular}

Coverage is defined as the presence of at least one Agency or Banking Correspondent in the municipality. Standard errors in parenthesis, clustered at the municipality level. Every regression on each column has the same number of observations. Controls used are $\log$ (GDP per Capita) and $\log$ (Population). ${ }^{*} p<0.1 ;^{* *} p<0.05$; ${ }^{* * *} p<0.01$. 
Despite not yielding significant estimates, the results in Table 6.4 corroborate the theory that the critical aspect of access to conditional cash transfer programs is the infrastructure coverage in each municipality. Conditional on Caixa's absence, it does not matter whether the family needs to withdraw its benefits in a close or a far away municipality. Traveling to another municipality entails high costs for these families, as stated in Section 6.2, because it means losing a day of work (when someone in the family is employed), having to arrange childcare, and buying an expensive bus ticket. 


\section{Conclusion}

This article studies the relationship between Public Banks and the distribution of CCT programs. First, I use an entry model with heterogeneous banks to determine the Bolsa Família program's impact on banking coverage. I find that, because Caixa values expanding coverage to reach potential beneficiaries, coverage was significantly accelerated in remote areas, with more than 1000 extra municipalities being covered at one point. Municipalities covered by Caixa are more impoverished, less populated, and have a higher percentage of PBF beneficiaries.

Then, exploiting variation in Caixa's coverage and Bolsa Família's cancellation rule, I estimate that Caixa's presence in a municipality reduces the number of cancellations of Bolsa Família by 9,9\%. Results are similar in an event-study model but with reductions in cancellations of up to $50 \%$ at the second month of banking coverage. Results also indicate that there is no anticipation, and the effects are somewhat lasting.

I also perform two robustness exercises. I use a similar approach to the main specification but replacing Caixa's coverage with the number of Caixa's per 10 thousand inhabitants and distance to the nearest Caixa. Effects remain significant in the first exercise, although smaller, but are not robust in the second. These results indicate that opening additional points of sale on previously covered municipalities or decreasing the distance to the nearest agency without covering the municipality are two ineffective policies. Traveling to another municipality entails high costs for these low-income families, but one point of sale is usually enough to guarantee satisfactory distribution of benefits.

This paper's main takeaway is that infrastructure plays an essential role in providing access to CCT programs in developing countries. Also, the distribution of policies may cause externalities to bank coverage. Specific to the Brazilian case, this paper finds that PBF improved banking coverage during the 2000s in remote and rural areas. Further work should verify if the extra coverage has further impacted poverty and inequality levels in these regions.

This paper results' bring a few direct policy implications: first, assuring that beneficiaries effectively access the program is an essential aspect of policy 
implementation. Second, using institutions with an aligned interest in policy distribution may be a valuable solution to guarantee access to benefits. Third, banking institutions' priorities may be just as relevant as competition effects to determine equilibrium coverage. 


\section{Bibliography}

BRESNAHAN, T. F.; REISS, P. C.. Entry and competition in concentrated markets. Journal of political economy, 99(5):977-1009, 1991.

FISZBEIN, A.; SCHADY, N. R.. Conditional cash transfers: reducing present and future poverty. The World Bank, 2009.

SOARES, F. V.; RIBAS, R. P. ; OSÓRIO, R. G.. Evaluating the impact of brazil's bolsa familia: Cash transfer programs in comparative perspective. Latin American Research Review, p. 173-190, 2010.

GERTLER, P.. Do conditional cash transfers improve child health? evidence from progresa's control randomized experiment. American economic review, 94(2):336-341, 2004.

GARCÍA, S.; SAAVEDRA, J. E.. Educational impacts and costeffectiveness of conditional cash transfer programs in developing countries: A meta-analysis. Review of Educational Research, 87(5):921965, 2017.

BARBER, S. L.; GERTLER, P. J.. Empowering women to obtain high quality care: evidence from an evaluation of mexico's conditional cash transfer programme. Health Policy and Planning, 24(1):18-25, 2009.

SHEI, A.; COSTA, F.; REIS, M. G. ; KO, A. I.. The impact of brazil's bolsa família conditional cash transfer program on children's health care utilization and health outcomes. BMC international health and human rights, 14(1):10, 2014.

ZUCCO JR, C.. When payouts pay off: Conditional cash transfers and voting behavior in brazil 2002-10. American journal of political science, 57(4):810-822, 2013.

JOAQUIM, G.; TOWNSEND, R. ; ZHORIN, V.. Optimal contracting and spatial competition among financial service providers. Technical report, Working Paper, 2019. 
GAO, H.; RU, H.; TOWNSEND, R. ; YANG, X.. Rise of bank competition: Evidence from banking deregulation in china. Technical report, National Bureau of Economic Research, 2019.

KUMAR, A.; NAIR, A.; PARSONS, A. ; URDAPILETTA, E.. Expanding bank outreach through retail partnerships. Correspondent Banks in Brazil, 2006.

ASSUNÇÃO, J.. Eliminating entry barriers for the provision of banking services: Evidence from 'banking correspondents' in brazil. Journal of Banking \& Finance, 37(8):2806-2811, 2013.

BANCO CENTRAL DO BRASIL. Relatório de inclusão financeira, n. 1, 2010.

MÜLLER, L. H.. Bancos na favela: Relações entre agências bancárias e moradores de uma região urbana alvo de políticas de pacificação. Tempo Social, 29(1):89-107, 2017.

COELHO, C. A.; DE MELLO, J. M. ; FUNCHAL, B.. The brazilian payroll lending experiment. Review of economics and statistics, 94(4):925-934, 2012.

COELHO, C. A.; DE MELLO, J. M. ; REZENDE, L.. Do public banks compete with private banks? evidence from concentrated local markets in brazil. Journal of Money, Credit and Banking, 45(8):1581-1615, 2013.

BURGESS, R.; PANDE, R.. Do rural banks matter? evidence from the indian social banking experiment. American Economic Review, 95(3):780-795, 2005.

ASSUNCAO, J.; MITYAKOV, S. ; TOWNSEND, R. M.. Ownership matters: the geographical dynamics of baac and commercial banks in thailand. Technical report, Citeseer, 2012.

WIJESIRI, M.; MARTÍNEZ-CAMPILLO, A. ; WANKE, P.. Is there a tradeoff between social and financial performance of public commercial banks in india? a multi-activity dea model with shared inputs and undesirable outputs. Review of Managerial Science, 13(2):417-442, 2019.

SAPIENZA, P.. The effects of government ownership on bank lending. Journal of financial economics, 72(2):357-384, 2004. 
COLEMAN, N.; FELER, L.. Bank ownership, lending, and local economic performance during the 2008-2009 financial crisis. Journal of Monetary Economics, 71:50-66, 2015.

ANDRADE, R. P. D.; DEOS, S.. A trajetória do banco do brasil no período recente, 2001-2006: banco público ou banco estatal" privado"? Revista de Economia Contemporânea, 13(1):47-79, 2009.

LOUREIRO, E.; MADEIRA, G. ; BADER, F.. Expansão dos correspondentes bancários no brasil: uma análise empírica. Texto para discussão, (433), 2011.

SOARES, F. V.; SOARES, S.; MEDEIROS, M. ; OSÓRIO, R. G.. Programas de transferência de renda no brasil: impactos sobre a desigualdade. 2006.

NERI, M. C.; VAZ, F. M. ; SOUZA, P. H. G. F. D.. Efeitos macroeconômicos do programa bolsa família: uma análise comparativa das transferências sociais. Programa Bolsa Família: uma década de inclusão e cidadania. Brasília: Ipea, 1:193-206, 2013.

RIBEIRO, F. G.; SHIKIDA, C. ; HILLBRECHT, R. O.. Bolsa família: Um survey sobre os efeitos do programa de transferência de renda condicionada do brasil. Estudos Econômicos (São Paulo), 47(4):805-862, 2017.

LIMA, A.; PAES, A.; SAMBIASE, A.; HULLEN, A.; RIBEIRO, B.; BORGES, C. ; OTHERS. Manual do pesquisador-programa bolsa família [internet]. Brasília: Ministério do Desenvolvimento Social, 2018.

MEDEIROS, M.; BRITTO, T. ; SOARES, F.. Programas focalizados de transferência de renda no brasil: contribuições para o debate. 2007.

REISS, P. C.. Empirical models of discrete strategic choices. The American Economic Review, 86(2):421-426, 1996.

MAZZEO, M. J.. Product choice and oligopoly market structure. RAND Journal of Economics, p. 221-242, 2002.

BAKER, A.; LARCKER, D. F. ; WANG, C. C.. How much should we trust staggered difference-in-differences estimates? Available at SSRN 3794018, 2021. 
ATHEY, S.; IMBENS, G. W.. Design-based analysis in difference-indifferences settings with staggered adoption. Technical report, National Bureau of Economic Research, 2018.

GOODMAN-BACON, A.. Difference-in-differences with variation in treatment timing. Technical report, National Bureau of Economic Research, 2018.

CALLAWAY, B.; SANT'ANNA, P. H.. Difference-in-differences with multiple time periods. Journal of Econometrics, 2020.

SUN, L.; ABRAHAM, S.. Estimating dynamic treatment effects in event studies with heterogeneous treatment effects. Journal of Econometrics, 2020. 


\section{Appendix}

\section{A.1 \\ Estimation Procedure}

Once the model predicts a unique equilibrium, the empirical estimation of the model is quite simple. It relies on the principle of revealed preference; if a specific outcome is observed on the market, it must be that this was the most profitable choice for each bank, given other bank's choices. The algorithm for the estimation is as follows: First, I draw k shocks $\left(\varepsilon_{c}, \varepsilon_{m}\right)$, which I assume follows a bivariate normal distribution. With these draws, I determine the economy's simulated equilibrium for each shock and a given value of the parameters. Then, I use the inequalities derived from the model (Equations $5-2,5-3$, and 5-4) to compute the number of times the observed outcomes are equal to the predicted in each market $m$. The product of these ratios generates a likelihood function of the parameters. The likelihood function is given by:

$$
L=\prod_{m} \frac{P_{m}\left(\alpha, \lambda, F, \Gamma_{c c}, \Gamma_{c o}, \Gamma_{o o}, \Gamma_{o c}\right)}{k}
$$

Where $P_{m}\left(\alpha, \lambda, F, \Gamma_{c c}, \Gamma_{c o}, \Gamma_{o o}, \Gamma_{o c}\right)$ is the number of times (out of $\mathrm{k}$ ) that the simulated outcome is equal to the observed outcome in market $m$. As $\mathrm{k}$ goes to infinity, this function converges to the probability of observing each market's outcomes, given the parameters. Maximizing the likelihood function with respect to the parameters $\left(\alpha, \lambda, F, \Gamma_{c c}, \Gamma_{c o}, \Gamma_{o o}, \Gamma_{o c}\right)$ yields the estimated values. In the reported results, $\mathrm{k}$ was set to 200 .

Since the objective function is a product of indicator functions, its surface is very rough and discontinuous, and optimizing it is a complex task. To solve this problem, I implement a smoothing procedure, similar to Mazzeo (2002), which consists of replacing each indicator function derived from the profit inequalities $I\left(\Pi_{i j}\right)$ with $\Phi\left(\Pi_{i j} / 0.1\right)$, where $\Phi$ is the cumulative normal distribution.

Finally, to generate standard errors for our estimates, I employed a bootstrapping scheme where $N$ samples with replacement were generated with the same size as our initial sample, and the parameters were estimated for each of the samples. Point estimation was the average of estimations, and standard 
errors are the standard deviation of the estimates. Because of computational limitations, $N$ was set to 100 .

\section{A.2 \\ Credit Trends}

Figure A.1: Credit per Municipality Trends
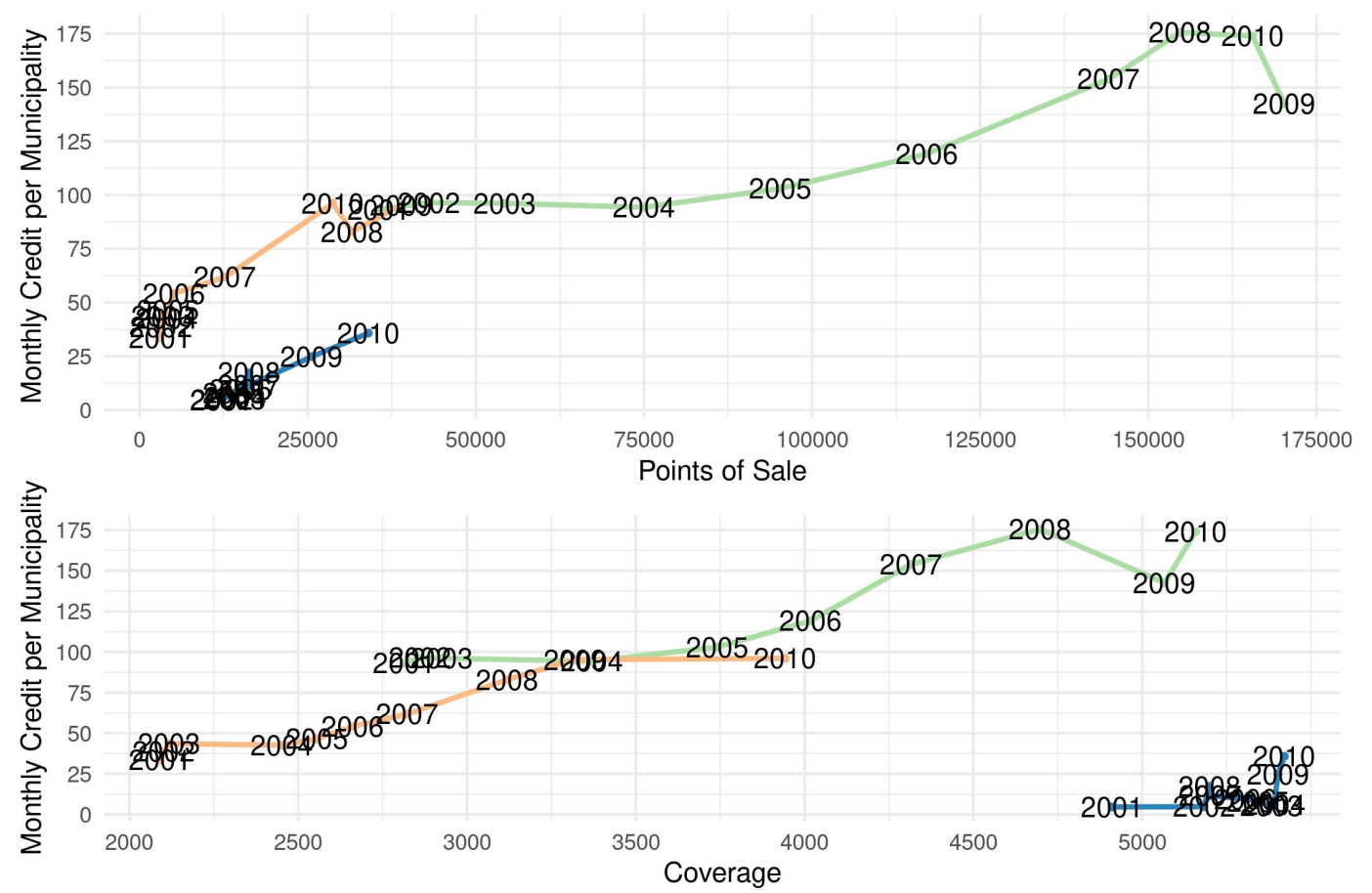

Banks - Banco do Brasil - Caixa - Private Banks

Notes: Both Agencies and Banking Correspondents were considered in the graph. Credit's unit is Million Reais (R\$). Each dot represents a year between 2001 and 2010. Version with year indicators. 
Figure A.2: Credit per Agency Trends
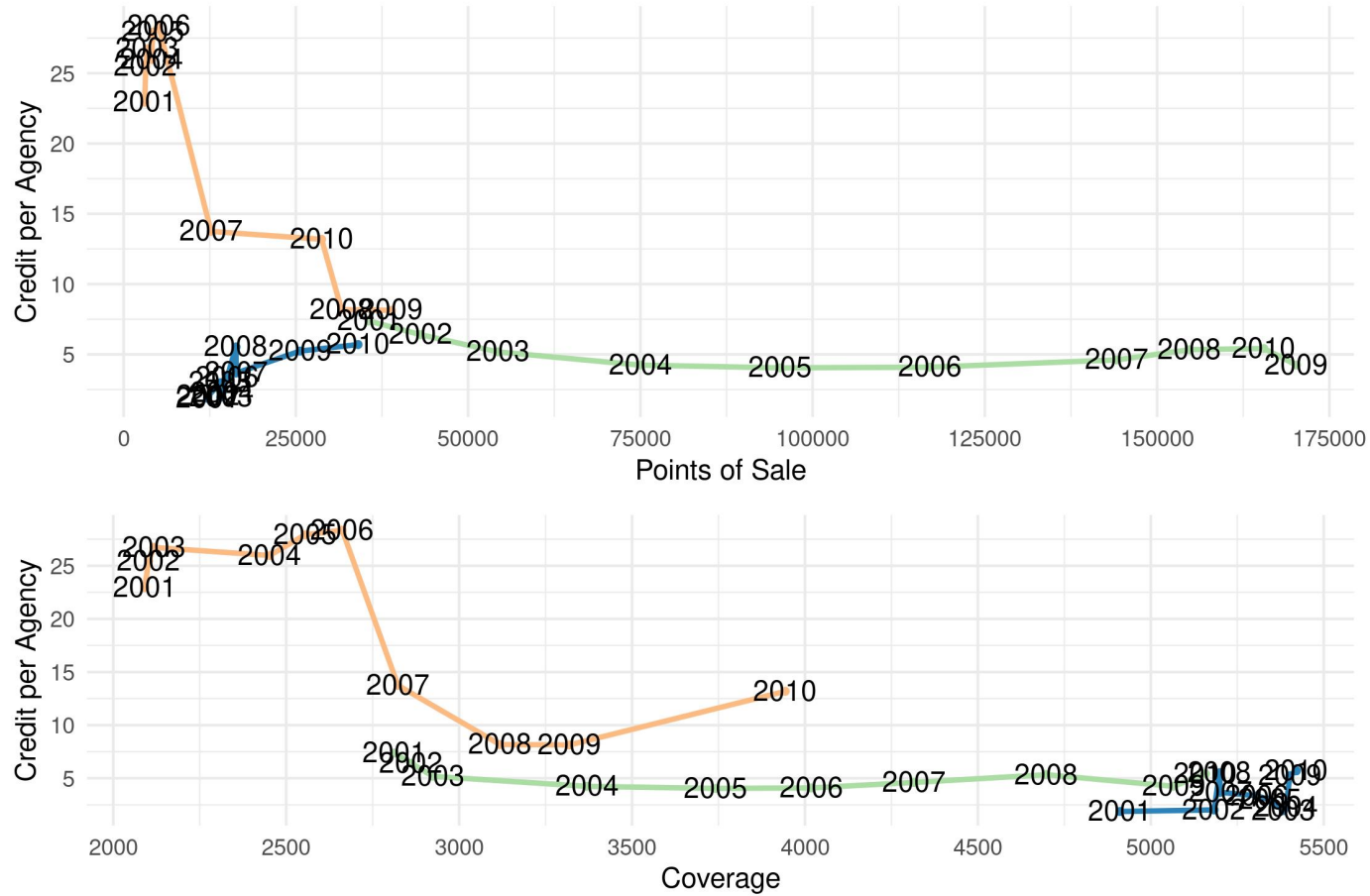

Banks - Banco do Brasil - Caixa - Private Banks

Notes: Both Agencies and Banking Correspondents were considered in the graph. Credit's unit is Million Reais (R\$). Each dot represents a year between 2001 and 2010. Version with year indicators. 


\section{A.3}

\section{Complete Estimates of the Model}

Table A.1: Complete Estimates of the Model

\begin{tabular}{|c|c|c|c|c|c|c|c|c|}
\hline Year & $\alpha$ & $\lambda$ & Ratio & $\mathrm{F}$ & $\Gamma_{c c}$ & $\Gamma_{c o}$ & $\Gamma_{o o}$ & $\Gamma_{o c}$ \\
\hline 2004 & $\begin{array}{c}3.72 \mathrm{e}-08 \\
(2.14 \mathrm{e}-07)\end{array}$ & $\begin{array}{c}1.48 \mathrm{e}-05 \\
(2.96 \mathrm{e}-05)\end{array}$ & $3.98 \mathrm{e}+02$ & $\begin{array}{c}6.29 \mathrm{e}-04 \\
(1.30 \mathrm{e}-03)\end{array}$ & $\begin{array}{c}9.77 \mathrm{e}-02 \\
(2.20 \mathrm{e}-03)\end{array}$ & $\begin{array}{c}1.00 \mathrm{e}-04 \\
(3.64 \mathrm{e}-04)\end{array}$ & $\begin{array}{c}1.28 \mathrm{e}-03 \\
(2.14 \mathrm{e}-03)\end{array}$ & $\begin{array}{c}1.21 \mathrm{e}-04 \\
(2.77 \mathrm{e}-04)\end{array}$ \\
\hline 2005 & $\begin{array}{c}4.06 \mathrm{e}-08 \\
(2.55 \mathrm{e}-07)\end{array}$ & $\begin{array}{c}1.76 \mathrm{e}-05 \\
(2.93 \mathrm{e}-05)\end{array}$ & $4.34 \mathrm{e}+02$ & $\begin{array}{c}7.63 \mathrm{e}-04 \\
(1.39 \mathrm{e}-03)\end{array}$ & $\begin{array}{c}9.74 \mathrm{e}-02 \\
(2.28 \mathrm{e}-03)\end{array}$ & $\begin{array}{c}5.51 \mathrm{e}-05 \\
(1.57 \mathrm{e}-04)\end{array}$ & $\begin{array}{c}1.51 \mathrm{e}-03 \\
(2.28 \mathrm{e}-03)\end{array}$ & $\begin{array}{c}7.07 \mathrm{e}-05 \\
(1.96 \mathrm{e}-04)\end{array}$ \\
\hline 2006 & $\begin{array}{c}6.51 \mathrm{e}-08 \\
(3.00 \mathrm{e}-07)\end{array}$ & $\begin{array}{c}1.18 \mathrm{e}-05 \\
(2.35 \mathrm{e}-05)\end{array}$ & $1.82 \mathrm{e}+02$ & $\begin{array}{c}6.62 \mathrm{e}-04 \\
(1.44 \mathrm{e}-03)\end{array}$ & $\begin{array}{c}9.65 \mathrm{e}-02 \\
(3.34 \mathrm{e}-03)\end{array}$ & $\begin{array}{c}1.14 \mathrm{e}-04 \\
(3.98 \mathrm{e}-04)\end{array}$ & $\begin{array}{c}2.41 \mathrm{e}-03 \\
(3.41 \mathrm{e}-03)\end{array}$ & $\begin{array}{c}5.10 \mathrm{e}-05 \\
(2.64 \mathrm{e}-04)\end{array}$ \\
\hline 2007 & $\begin{array}{c}6.33 \mathrm{e}-08 \\
(3.65 \mathrm{e}-07)\end{array}$ & $\begin{array}{c}5.12 \mathrm{e}-06 \\
(1.80 \mathrm{e}-05)\end{array}$ & $8.09 \mathrm{e}+01$ & $\begin{array}{c}9.66 \mathrm{e}-04 \\
(1.82 \mathrm{e}-03)\end{array}$ & $\begin{array}{c}9.53 \mathrm{e}-02 \\
(4.56 \mathrm{e}-03)\end{array}$ & $\begin{array}{c}6.52 \mathrm{e}-05 \\
(2.59 \mathrm{e}-04)\end{array}$ & $\begin{array}{c}3.29 \mathrm{e}-03 \\
(4.72 \mathrm{e}-03)\end{array}$ & $\begin{array}{c}1.44 \mathrm{e}-04 \\
(5.06 \mathrm{e}-04)\end{array}$ \\
\hline 2008 & $\begin{array}{c}1.10 \mathrm{e}-07 \\
(3.26 \mathrm{e}-07)\end{array}$ & $\begin{array}{c}8.02 \mathrm{e}-06 \\
(3.15 \mathrm{e}-05)\end{array}$ & $7.30 \mathrm{e}+01$ & $\begin{array}{c}1.18 \mathrm{e}-03 \\
(2.52 \mathrm{e}-03)\end{array}$ & $\begin{array}{c}9.32 \mathrm{e}-02 \\
(6.03 \mathrm{e}-03)\end{array}$ & $\begin{array}{c}9.69 \mathrm{e}-05 \\
(3.23 \mathrm{e}-04)\end{array}$ & $\begin{array}{c}5.06 \mathrm{e}-03 \\
(6.41 \mathrm{e}-03)\end{array}$ & $\begin{array}{c}7.82 \mathrm{e}-05 \\
(2.42 \mathrm{e}-04)\end{array}$ \\
\hline 2009 & $\begin{array}{c}3.88 \mathrm{e}-08 \\
(4.27 \mathrm{e}-07)\end{array}$ & $\begin{array}{c}1.06 \mathrm{e}-05 \\
(2.80 \mathrm{e}-05)\end{array}$ & $2.74 \mathrm{e}+02$ & $\begin{array}{c}1.01 \mathrm{e}-03 \\
(2.06 \mathrm{e}-03)\end{array}$ & $\begin{array}{c}9.06 \mathrm{e}-02 \\
(9.28 \mathrm{e}-03)\end{array}$ & $\begin{array}{c}1.04 \mathrm{e}-04 \\
(2.87 \mathrm{e}-04)\end{array}$ & $\begin{array}{c}7.88 \mathrm{e}-03 \\
(9.34 \mathrm{e}-03)\end{array}$ & $\begin{array}{c}1.33 \mathrm{e}-04 \\
(5.14 \mathrm{e}-04)\end{array}$ \\
\hline 2010 & $\begin{array}{c}1.33 \mathrm{e}-07 \\
(3.52 \mathrm{e}-07)\end{array}$ & $\begin{array}{c}1.28 \mathrm{e}-05 \\
(2.65 \mathrm{e}-05)\end{array}$ & $9.62 \mathrm{e}+01$ & $\begin{array}{c}2.27 \mathrm{e}-04 \\
(5.81 \mathrm{e}-04)\end{array}$ & $\begin{array}{c}9.00 \mathrm{e}-02 \\
(1.06 \mathrm{e}-02)\end{array}$ & $\begin{array}{c}6.33 \mathrm{e}-05 \\
(1.62 \mathrm{e}-04)\end{array}$ & $\begin{array}{c}9.44 \mathrm{e}-03 \\
(1.07 \mathrm{e}-02)\end{array}$ & $\begin{array}{c}8.34 \mathrm{e}-05 \\
(3.16 \mathrm{e}-04)\end{array}$ \\
\hline 2011 & $\begin{array}{c}1.04 \mathrm{e}-07 \\
(3.05 \mathrm{e}-07)\end{array}$ & $\begin{array}{c}9.94 \mathrm{e}-06 \\
(2.40 \mathrm{e}-05)\end{array}$ & $9.57 \mathrm{e}+01$ & $\begin{array}{c}1.36 \mathrm{e}-04 \\
(3.77 \mathrm{e}-04)\end{array}$ & $\begin{array}{c}8.76 \mathrm{e}-02 \\
(1.33 \mathrm{e}-02)\end{array}$ & $\begin{array}{c}2.97 \mathrm{e}-05 \\
(1.80 \mathrm{e}-04)\end{array}$ & $\begin{array}{c}1.20 \mathrm{e}-02 \\
(1.33 \mathrm{e}-02)\end{array}$ & $\begin{array}{c}5.64 \mathrm{e}-05 \\
(1.66 \mathrm{e}-04)\end{array}$ \\
\hline 2012 & $\begin{array}{c}2.91 \mathrm{e}-07 \\
(4.64 \mathrm{e}-07)\end{array}$ & $\begin{array}{l}-6.00 \mathrm{e}-06 \\
(2.94 \mathrm{e}-05)\end{array}$ & $-2.06 \mathrm{e}+01$ & $\begin{array}{c}1.16 \mathrm{e}-04 \\
(4.39 \mathrm{e}-04)\end{array}$ & $\begin{array}{c}5.83 \mathrm{e}-02 \\
(2.43 \mathrm{e}-02)\end{array}$ & $\begin{array}{c}3.60 \mathrm{e}-05 \\
(1.75 \mathrm{e}-04)\end{array}$ & $\begin{array}{c}4.14 \mathrm{e}-02 \\
(2.45 \mathrm{e}-02)\end{array}$ & $\begin{array}{c}3.72 \mathrm{e}-05 \\
(2.25 \mathrm{e}-04)\end{array}$ \\
\hline 2013 & $\begin{array}{c}3.37 \mathrm{e}-07 \\
(4.19 \mathrm{e}-07)\end{array}$ & $\begin{array}{c}-7.28 \mathrm{e}-06 \\
(3.84 \mathrm{e}-05)\end{array}$ & $-2.16 \mathrm{e}+01$ & $\begin{array}{c}1.29 \mathrm{e}-04 \\
(3.18 \mathrm{e}-04)\end{array}$ & $\begin{array}{c}5.98 \mathrm{e}-02 \\
(2.19 \mathrm{e}-02)\end{array}$ & $\begin{array}{c}3.25 \mathrm{e}-05 \\
(2.71 \mathrm{e}-04)\end{array}$ & $\begin{array}{c}4.00 \mathrm{e}-02 \\
(2.18 \mathrm{e}-02)\end{array}$ & $\begin{array}{c}6.97 \mathrm{e}-06 \\
(1.64 \mathrm{e}-04)\end{array}$ \\
\hline 2014 & $\begin{array}{c}3.95 \mathrm{e}-07 \\
(4.73 \mathrm{e}-07)\end{array}$ & $\begin{array}{c}8.93 \mathrm{e}-06 \\
(3.79 \mathrm{e}-05)\end{array}$ & $2.26 \mathrm{e}+01$ & $\begin{array}{c}1.05 \mathrm{e}-04 \\
(2.91 \mathrm{e}-04)\end{array}$ & $\begin{array}{c}6.98 \mathrm{e}-02 \\
(1.92 \mathrm{e}-02)\end{array}$ & $\begin{array}{l}-1.07 \mathrm{e}-05 \\
(3.38 \mathrm{e}-04)\end{array}$ & $\begin{array}{c}3.00 \mathrm{e}-02 \\
(1.92 \mathrm{e}-02)\end{array}$ & $\begin{array}{c}7.38 \mathrm{e}-06 \\
(2.12 \mathrm{e}-04)\end{array}$ \\
\hline 2015 & $\begin{array}{c}2.41 \mathrm{e}-07 \\
(4.29 \mathrm{e}-07)\end{array}$ & $\begin{array}{c}2.52 \mathrm{e}-06 \\
(2.80 \mathrm{e}-05)\end{array}$ & $1.05 \mathrm{e}+01$ & $\begin{array}{c}6.60 \mathrm{e}-05 \\
(1.96 \mathrm{e}-04)\end{array}$ & $\begin{array}{c}7.20 \mathrm{e}-02 \\
(1.88 \mathrm{e}-02)\end{array}$ & $\begin{array}{c}4.03 \mathrm{e}-05 \\
(1.80 \mathrm{e}-04)\end{array}$ & $\begin{array}{c}2.78 \mathrm{e}-02 \\
(1.88 \mathrm{e}-02)\end{array}$ & $\begin{array}{c}-1.61 \mathrm{e}-05 \\
(2.27 \mathrm{e}-04)\end{array}$ \\
\hline 2016 & $\begin{array}{c}2.35 \mathrm{e}-07 \\
(3.81 \mathrm{e}-07)\end{array}$ & $\begin{array}{c}-2.53 \mathrm{e}-06 \\
(4.12 \mathrm{e}-05)\end{array}$ & $-1.08 \mathrm{e}+01$ & $\begin{array}{c}7.86 \mathrm{e}-05 \\
(2.62 \mathrm{e}-04)\end{array}$ & $\begin{array}{c}6.73 \mathrm{e}-02 \\
(2.09 \mathrm{e}-02)\end{array}$ & $\begin{array}{c}2.46 \mathrm{e}-05 \\
(2.61 \mathrm{e}-04)\end{array}$ & $\begin{array}{c}3.26 \mathrm{e}-02 \\
(2.09 \mathrm{e}-02)\end{array}$ & $\begin{array}{c}-3.24 \mathrm{e}-05 \\
(2.24 \mathrm{e}-04)\end{array}$ \\
\hline 2017 & $\begin{array}{c}2.60 \mathrm{e}-07 \\
(3.77 \mathrm{e}-07)\end{array}$ & $\begin{array}{l}-1.10 \mathrm{e}-05 \\
(3.73 \mathrm{e}-05)\end{array}$ & $-4.23 e+01$ & $\begin{array}{c}1.06 \mathrm{e}-04 \\
(3.27 \mathrm{e}-04)\end{array}$ & $\begin{array}{c}6.31 \mathrm{e}-02 \\
(2.34 \mathrm{e}-02)\end{array}$ & $\begin{array}{c}3.32 \mathrm{e}-05 \\
(1.13 \mathrm{e}-04)\end{array}$ & $\begin{array}{c}3.67 \mathrm{e}-02 \\
(2.34 \mathrm{e}-02)\end{array}$ & $\begin{array}{c}2.41 \mathrm{e}-05 \\
(1.50 \mathrm{e}-04)\end{array}$ \\
\hline
\end{tabular}

Notes: Ratio is not directly estimated from the model. It is defined as $\frac{\lambda}{\alpha}$. 